\title{
İslam Hukuk Usulünde Müşterek Lafzın Manaya Delaletine Dair Tartışmalar
}

\author{
Mahmut Samar \\ Dr. Öğr. Üyesi, Ankara Sosyal Bilimler Üniversitesi (ROR ID: 025y36b60) \\ İslami İlimler Fakültesi, İslam Hukuku Anabilim Dalı \\ Assistant Professor Dr., Social Sciences University of Ankara Faculty of Islamic Studies \\ Department of Islamic Law \\ Ankara/Turkey \\ mahmutsamar@hotmail.com \\ ORCID: 0000-0001-2345-6789
}

\section{Discussions on the Denotation of the Common Term (al-Lafz al-Mushtaraq) to the Meaning in Methodology of Islamic Law}

\begin{abstract}
Al-Kitāb and the Sunnah (Prophetic tradition) are two basic sources of Islamic law that have become text in the historical process. To understand the nass in these two sources and to determine the best way for them are one of the most important issues of Islamic law. Science of alfāz (the wordings of the terms) in methodology of fiqh is a significant section that includes required rules in this sense. The controversies on fiqh generally depend on the meanings of the words which build the nass and to the decisions that acquire from these meanings. The reason is that science of alfāz includes the rules of making decisions from nass. Because of that alfāz has an extensive space in fiqh literature.

The terms (alfāz) are subjected to taxonomy from different angles. In this respect there are four categories and twenty-four terms which are extremely significant. Because without the knowledge of the classification of alfāz, their relations with each other and hierarchy of them, it is hard to understand nass correctly. According to the aforementioned division, firstly the terms (alfāz) which their meanings were given are examined. There are four types of terms (alfāz) in this category which are also known as terms in terms of meaning or extent. These are ‘̄̄mm, hāss, common, and muawwal terms. From these hāss has four parts; command, prohibition, mutlaq and muqayyad. Secondly, the terms (alfāz) which in terms of their use for meaning are examined. In this group there are haqiqah (truth), macaz (metaphoric meaning), sarih (understandable) and qinaya (allusion). Thirdly, explicit and implicit terms in terms of the meaning are examined. They are totally eight terms that four of them explicit and other four of them implicit. Explicit terms are zāhir, nass, mufassar and muhqam. Implicit terms are hafi, mushqil, mujmal and mutashābih. Lastly, the terms depend on the shape of indication to the meaning are examined. These terms are indication of phrase, indication of mark, indication of nass and
\end{abstract}

\footnotetext{
İntihal Taraması/Plagiarism Detection: Bu makale intihal taramasından geçirildi/This paper was checked for plagiarism Geliş/Received: 04 Temmuz/July 2020|Kabul/Accepted:09 Eylül/September 2020 | Yayın/Published: 20 Eylül/September 2020 Atff/Cite as: Mahmut Samar, "İslam Hukuk Usulünde Müşterek Lafzın Manaya Delaletine Dair Tartışmalar = Discussions on the Denotation of the Common Term (al-Lafz al-Mushtaraq) to the Meaning in Methodology of Islamic Law", Eskiyeni 42 Eylül/September 2020), 961-984. https://doi.org/10.37697/eskiyeni.764230

Copyright @ Anadolu İlahiyat Akademisi/Anatolian Theological Academy, 06050, Ankara, Turkey | www.anilakademi.com CC BY-NC 4.0 | This paper is licensed under a Creative Commons Attribution-NonCommercial License
} 
indication of demand. This separation belongs to Hanefite school of law, and Shaafite school of law also examined it. But there are some differentiations on separation and arranging between them.

On the other hand, there are also different approaches on provisions of the terms; and certitude and supposition of them. An argument in this respect is about the common term and its publicity. The common term as a subject in many scientific fields becomes one of the important subjects of Islamic law about indications of the terms. This subject is significant in many theoretical discussions and crucial to determine the judgement in many juristic issues. The scholars of figh put forward their ideas on the possibility, meaning, reasons, provision and publicity of the common term and made a rich literature. The common term as a reason for discussions caused to many arguments in the field. It is a comprehensive subject that nearly held in all areas of Islamic literature.

Today contribution of the term (ألاشتراك اللفظي) is known as polysemy and the common term as one of the important elements of it may be seen in all languages. Today, the contribution of the term to the meaning becomes important to be an interdisciplinary subject. Polysemy is a wellknown subject in many academic fields but although it is one of the significant areas of fiqh, there is no work that holds this subject in terms of Turkish language. To aim of this study is to fill that blank in Turkish literature and become the first step to that field. Therefore, this study focuses on the common terms in methodology of Islamic law. The aim of the study is to see the effect of the polysemic words (associations) of the language on controversies in fiqh, and thus to determine the role of fiqh scholars in reaching to different provisions on the same subject. For this purpose, the study focused on the place of the common term in the literature, its lexical and terminological meaning and also, the reasons of polysemic terms. Subsequently, the judgment and the publicity of the common terms were dealt with in a comparative way. Finally, the study was completed with the results which were achieved.

\section{Keywords}

Islamic Law, Methodology of Islamic Law, Polysemic Terms, Denotation

\section{İslam Hukuk Usulünde Müşterek Lafzın Manaya Delaletine Dair Tartışmalar Öz}

Kitap ve sünnet İslam hukukunun tarihi süreç içerisinde metin halini almış iki temel kaynağıdır. Bu iki kaynakta yer alan nasları anlamak ve bunun için doğru bir yöntem belirlemek İslam hukuk usulünün en önemli konularından biridir. Fıkıh usulünde lafızlar (elfâz) bahsi bu anlamda ihtiyaç duyulan kuralları içeren önemli bir bölümdür. Fıkhî anlamdaki ihtilafların çoğu nasları inşa eden lafızlara yüklenen manalara ve bu manalardan elde edilen hükümlere dayanır. Çünkü lafızlar (elfâz) bahsi, naslardan hüküm çıkarmada ihtiyaç duyulan kuralları ihtiva eder. Bu nedenledir ki fikıh usulü alanında kaleme alınmış eserlerde lafızlara genişçe yer verildiği görülür.

Lafızlar, farklı açılardan taksime tabi tutularak incelenir. Bu çerçevede dört kategoride yirmi dört lafız üzerinde titizlikle durulmaktadır. Çünkü lafızların tasnifi, birbiriyle ilişkisi, hiyerarşisi bilinmeden nasların doğru bir şekilde anlaşılması oldukça güçtür. Söz konusu taksime göre ilk sırada "vaz' olunduğu mana bakımından lafızlar" yer alır. Kapsadığı mana bakımından veya şümul bakımından lafızlar olarak da bilinen bu kategoride dört lafız türü bulunur. Bunlar; âm, hâs, müşterek ve müevvel lafızlardır. Bunlardan hâss lafız ise emir, nehiy, mutlak ve mukayyed k1sımlarına ayırılır. İkinci sırada kullanıldığı mana bakımından lafızlar incelenir. Bu grupta hakikat, mecaz, sarih ve kinaye lafızları yer alır. Üçüncü olarak manaya delaletinin açık veya kapalı 
olması bakımından lafızlar ele alınır. Bunlar; dördü açık, dördü de kapalı olmak üzere sekiz lafızdan oluşur. Açık lafızlar; zahir, nass, müfesser ve muhkem. Kapalı lafızlar; hafî, müşkil, mücmel ve müteşabih. Son sırada manaya delaletinin şekli bakımından lafızlar üzerinde durulur. Bu lafızlar da ibarenin delaleti, işaretin delaleti, nassın delaleti ve iktizanın delaleti olmak üzere dört kısımdır. Bu taksim Hanefî/fukahâ metodunu benimseyen usûlcülere aittir. Mütekellimin/Şâfiî usûlcüleri de bu lafizları incelemiş̧lerdir. Ancak iki yöntem arasında taksimde, sıralamada vs. bazı farklar söz konusudur.

Öte taraftan bazı lafızların hükümleri, manaya delaletinin katîliği ve zanniliği gibi hususlarda iki yöntem arasında farklı yaklaşımlar bulunmaktadır. Bu kapsamda tartışılan konulardan biri müşterek lafız ve umûmiliği meselesidir. Birçok ilmi disiplinin ilgi alanına giren müşterek lafız olgusu, İslam hukuk usulünde lafızların delaleti bahsinin en önemli konularından birini oluşturur. Teorik açıdan zengin tartışmaların yapılmasında ve birçok hukuki işlemin hükmünü belirlemede önemli bir role sahiptir. Fıkıh usulü bilginleri müşterek lafzın imkânı, anlamı, sebepleri, hükmü ve umumu gibi konularda düşüncelerini ortaya koyarak bu konuda klasik metinlerde zengin bir literatür oluşmasını sağlamışlardır. Müşterek lafız, birçok ihtilafın sebebi olarak yoğun tartışmaların yaşanmasına yol açmıştır. Neredeyse İslami ilimlerin tamamında bir şekilde literatüre girmiş kapsamlı bir konudur. Günümüzde çok anlamlılık (polysemy) olarak ifade edilen lafzî iştirak (ألاشتراك اللفظي) ve bunun en temel ögesi olan müşterek lafız hadisesi hemen tüm dillerde görülen ortak bir olgudur. Lafızlarda mana bakımından iştirak konusu, bugün disiplinlerarası çalışmalara konu olacak kadar önemli bir mesele haline gelmiştir. Farklı alanlarda birçok akademik çalışmada ele alınan çok anlamlılık olgusu, fıkıh usulünün en temel meselelerinden biri olmasına rağmen özellikle Türkçe literatürde henüz konuyu doğrudan ele alan bir çalışma yoktur. Türkçe literatürde bir boşluğu doldurması ve bu konuda ilk adım olması hedefiyle ortaya konulan bu çalışma İslam hukuk usulünde müşterek lafzı konu edinmektedir. Çalışmanın amacı dilde çok anlamlılık (iştirak) olgusunun fıkıh usulündeki ihtilaflar üzerinde etkisini görmek ve böylece fıkıh alimlerinin aynı konuda farklı hükümlere ulaşmalarındaki rolünü tespit etmektir. Bu amaçla çalışmada elfâz bahislerine dair kısa bir girişten sonra müşterek lafzın literatürdeki yeri, sözlük ve terim anlamı ile çok anlamlılı̆̆ın sebepleri üzerinde duruldu. Ardından müşterekin hükmü ve umumu konuları mukayeseli bir yöntemle ele alındı. Son olarak ulaşılan neticelere yer verilerek çalıșma tamamlandı.

\section{Anahtar Kelimeler}

İslam Hukuku, Fıkıh Usulü, Çok anlamlılık, Müşterek, Umûmu'l-müşterek

\section{Giriş}

Klasik fikıh usulünün en temel kabullerinden biri ittifak edilen şerî delillerin Kitap, sünnet, icma ve kıyas şeklindeki hiyerarşik sıralamasıdır. Ancak icma ve kıyasın diğer iki delile dayandığı göz önünde bulundurulursa aslî delillerin Kitap ve sünnet olduğu kendiliğinden ortaya çıkar. Başta Kitap olmak üzere bu iki delilin yazılı birer metin (nass) olması, klasik fikıh usulünde delillerden hüküm çıkarma yolları (istinbat) ile ilgili kuralların geliştirilmesini gerekli kılmıştır. Bu iki delilin Arapça olmasından hareketle, Arap diline göre lafizların hangi mana için konmuş (vaz') olduğu, konmuş oldukları manada kullanılıp kullanılmadığı, manaya delaletinin açıklık ve kapalılık dereceleri ve manaya delalet şekli anlaşılmadan Kitap ve sünnet metinlerini doğru 
şekilde anlamak ve mevcut hükümlerle irtibatlarını isabetli biçimde kurmak mümkün değildir. Özetle ifade etmek gerekirse çeşitli yönleriyle lafızlar (elfâz) anlaşılmadan nasları anlamanın ve anlamlandırmanın imkânı yoktur.

Klasik fikıh usulüne göre delillerden hüküm çıkarma yolları yani lafızlar bahsi dörtlü taksime tabi tutularak incelenir. (1) Vaz‘ olunduğu mana bakımından lafızlar. Bunlar; hâs, âmm, müşterek ve müevvel olmak üzere dört lafızdır. Bunlardan hâss lafız ise emir, nehiy, mutlak ve mukayyed kısımlarına ayırılır. (2) Kullanıldığı mana bakımından lafızlar. Bu grupta hakikat, mecaz, sarih ve kinaye lafızları yer alır. (3) Manaya delaletinin açık veya kapalı olması bakımından lafızlar. Bunlar; dördü açık, dördü de kapalı olmak üzere sekiz lafızdan oluşur. Açık lafızlar; zahir, nass, müfesser ve muhkem. Kapalı lafızlar; hafî, müşkil, mücmel ve müteşabih. (4) Manaya delaletinin şekli bakımından lafızlar. Bu lafızlar da ibarenin delaleti, işaretin delaleti, nassın delaleti ve iktizanın delaleti olmak üzere dört kısımdır. ${ }^{1}$ Elfâz bahsinde Kur'ân ve sünnet lafızlarının çeşitli açılardan yapısı ve manaya delalet şekilleri incelenmektedir. Esas itibariyle lafız mana ilişkisi ve lafzın manaya delaletinin tespiti yapılmaktadır. Bu yönüyle bu bölüm fikıh usulünde kaynaklardan hüküm çıkarma (istinbât/istidlâl) metotları olarak karşımıza çıkmaktadır.

Bu taksim Hanefî/fukahâ metodunu benimseyen usûlcülere aittir. Mütekellimin/Şâfiî usûlcüleri de bu lafızları incelemişlerdir. Ancak iki yöntem arasında taksimde, sıralamada vs. bazı farklar söz konusudur. Söz gelimi Gazzâlî (öl. 505/1111) lafızları, vaz‘ olundukları mana ve dil açısından dört başlık altında incelemiştir. Bunlar; "mücmel ve mübeyyen", "zahir ve müevvel", "emir ve nehiy", "âmm ve hâs” şeklindedir. ${ }^{2}$ Mahallînnin (öl. 864/1459) taksimi ise mananın tekliği ve çokluğu açısından lafızlar şeklinde olmuştur. ${ }^{3}$ Yine bazı lafızların hükümleri, manaya delaletinin katîliği ve zanniliği gibi hususlarda iki yöntem arasında farklı yaklaşımlar bulunmaktadır. Bu kapsamda tartışılan konulardan biri müşterek lafiz ve umûmiliği meselesidir. Birçok ilmi disiplinin ilgi alanına giren müşterek lafız olgusu, İslam hukuk usulünde lafızların delaleti bahsinin en önemli konularından birini oluşturur. Teorik açıdan zengin tartışmaların yapılmasında ve birçok hukuki işlemin hükmünü belirlemede önemli bir role sahiptir. Fıkıh usulü bilginleri müşterek lafzın imkânı, anlamı, sebepleri, hükmü ve umumu gibi konularda düşüncelerini ortaya koyarak bu konuda klasik metinlerde zengin bir literatür oluşmasını sağlamışlardır.

Günümüzde çok anlamlılık (polysemy) olarak ifade edilen lafzî iştirak (ألاشتراك ve bunun en temel ögesi olan müşterek lafız hadisesi hemen tüm dillerde görülen ortak bir olgudur. Lafızlarda mana bakımından iştirak konusu, bugün disiplinle-

1 Kasım İbn Kutluboğa, Hülâsatül-efkâr şerhu Muhtasari'l-Menâr, thk. Hafız Senaullah ez-Zâhidî (Beyrut: Dâr İbn Hazm, 2003), 51 vd.

2 Ebû Hâmid Gazzâlî, el-Müstasfâminilmi'l-usûl, thk. Muhammed Süleyman el-Aşkar (Beyrut: Müessesetü’rRisâle, 2012), 1/180.

3 Celâleddîn Mahallî, el-Bedrü't-tâli fî halli Cem'i'l-cevâmi' (Beyrut: Müessesetü'r-Risâle, 2005), 1/223. 
rarası çalışmalara konu olacak kadar önemli bir mesele haline gelmiştir. Farklı alanlarda birçok akademik çalışmada ele alınan çok anlamlılık olgusu, fikıh usulünün en temel meselelerinden biri olmasına rağmen özellikle Türkçe literatürde henüz konuyu doğrudan ele alan bir çalışma yoktur. Fıkıh usulü zaviyesinden müşterek lafız konusuyla ilgili yapılan sınırlı sayıdaki çalışmaların tamamına yakını Arap dünyasinda ortaya konmuştur. ${ }^{4}$

Türkçe literatürde bir boşluğu doldurması ve bu konuda ilk adım olması hedefiyle bu çalışmada fikıh usulünde müşterek lafız ekseninde ortaya çıkan tartışmalardan hareketle usulcülerin yaklaşımlarını tespit etmeye gayret edeceğiz. Bu yaklaşımların nedenlerini, fikhi bilgi üretimine etkilerini ve sonuçlarına dair resmi görmeye çalışacağız. Bu amaçla öncelikle dil ve istılah açısından "müşterek" lafzı ele alacağız. Ardından müşterek lafzın umumiliği meselesine yer vereceğiz.

\section{Müşterek Lafzın Literatürdeki Yeri ve Anlamı}

Dilde kural olarak, her lafız tek bir manayı ifade etmek için vaz‘ olunur. Nahiv bilginlerinin kelimeyi "müfred mana için türetilmiş lafizdır" şeklinde tanımlamaları bu hususa işaret etmektedir. Ne var ki neredeyse bütün dillerde olduğu gibi Arap dilinde de eş anlamlı (müradif), zıt anlamlı (ezdâd) ve çok anlamlı (müşterek) lafızlar bulunmaktadır. Müslüman ilim adamları arasında bir lafzın hakiki manada çok anlamlı olmasının imkanını kabul etmeyenler olsa da genel kanaat aksi yöndedir. ${ }^{6}$ Lafizlarda iştiraki kabul etmeyenlerin en kuvvetli argümanı, müşterek lafızların konuşmada/yazıda kastedilen anlamın tam olarak anlaşılmamasına yol açması ve bunun çekişmelere ve sorunlara neden olacağıdır. İştirakin vacip veya mümkün ve vâki olduğunu kabul edenler ise manaların sınırsızlı̆̆ına karşılık lafızların sınırlı olmasına dikkat çekerler. Konu teorik zeminde bu şekilde tartışıllyor olsa da hem dilde hem de İslam hukukunun ana kaynaklarında (naslar) tümevarım yoluyla tespit edildiği üzere müşterek lafızların varlığı açıkça görülmektedir. ${ }^{7}$

Konuyla ilgili bir diğer tartışma; Allah ve Rasûlü'nün kelamında (âyet ve hadislerde) iştirakin imkânı ve husulü konusundadır. Bunu kabul etmeyenler, ikisinin kelamının muhatap (mükellef) tarafından anlaşılmasının gerekliliğine dikkat çekerler. Aksi takdirde kişi gücünü aşan bir şeyle mükellef kılınmış (teklif-i mâlâ yutak) olur ve bu caiz

4 Konuyla ilgili yapılan önemli çalş̧malar: Abdullah Muhammed Nuri ed-Dirşevî, "Mezâhibü'l-Usûliyyîn fi isti 'mâli'l-müşterek fî meânîhi meân", Journal of Faculty of Sharia 20/20 (2002), 226-280; Abdülhalik Şefâa, "el-Müşterekü'l-lafzî ve'l-manevî ve eseruhumâ fî ğumûdi'n-nas", Al-Qānūn 13/1 (2016), 1-25; Mahbûb Kahtân, "Delâletü'l-müşterek inde'l-usûliyyin”, Mecellet Külliyeti'ş-şsîa 3 (2012), 1-24.

5 İbn Hişâm, Şerh Katri'n-nedâ ve belli'sadâ, thk. Muhammed Muhyiddin Abdülhamit (Kahire, 1383 ), 10.

6 Alâeddîn Semerkandî, Mizânül'-usûl fí netâicil'-ukûl, thk. Muhammed Zeki Abdüler (Doha: Matâbi'u'dDoha el-Hadîse, 1984), 337; Şemseddin İbn Müflih, Usûlül'-fikh, thk. Fahd. b. Muhammed es-Sedehân (Riyad: Mektebetü'l-'Ubeykân, 1999), 1/61; Bahrülulûm Leknevî, Fevâtihu'r-rahamût fişserhi Müsellemi's-sübût, thk. Abdullah Mahmud Muhammed Ömer (Beyrut: Dâru'l-Kütübi'l-ilmiyye, 2002), 1/161.

7 Fahreddîn Râzî, el-Mahsûl, thk. Taha Cabir Feyyaz Ulvânî (Beyrut: Müessesetü’r-Risâle, 1997), 262-264; Muhammed b. Ali Şevkânî, İrşâdül'-fuhûl ilâ tahkikil'-hak min ilmi'-usûl, trc. Ahmed Azzo İnâye (Beyrut: Dâru'l-Kitâbi'l-Arabî, 1999), 1/57-58. 
değildir. Oysa müşterek lafzın hangi manada kullanıldığı beyan edilmezse manası kapalı kalır. Şayet bir açıklama ile birlikte kullanılırsa bu sözün gereksiz yere uzatılması anlamına gelir ki abesle iştigaldir. Ne var ki naslarda müşterek lafzın vuku bulduğuna dair örneklerin varlığı ve manasının bir şekilde anlaşılmış olması bu itirazı yersiz kılmaktadir. ${ }^{8}$

Çok anlamlı lafızlar, nasları anlama ve yorumlamadaki ihtilafın en temel sebeplerinden biridir. ${ }^{9}$ Bu nedenle çok anlamlılık (müşterek) konusu, dil bilginlerinin yanı sıra tefsir alimleri ve usûlcüler tarafından da önemsenmiş bir meseledir. Nitekim Kur'ân ilimlerinde erken dönemlerden itibaren Kur'ân'da geçen müşterek lafızların toplandığı el-vücûh ve'n-nezâir adıyla bir yazım türü gelişmiştir. Bu yazım türünün ilk kısmı olan vücûh, birden çok anlamı olan müşterek lafızları ifade eden bir terimdir. ${ }^{10}$ Müşterek lafız olgusu çok erken dönemlerden itibaren Arap dilbilimcilerin de gündeminde olan bir konudur. Öyle ki lafızlarda iştirak dilsel bir olgu olarak hicri ikinci asırdan itibaren literatürde yer almaya başlamış ve hicri üçüncü asrın sonlarına doğru konuyla ilgili müstakil ve kapsamlı çalışmalar ortaya çıkmıştır. ${ }^{11}$

Gerek Kur'ân ilimleri gerekse de Arap dili alanlarında müşterek lafız konusuyla ilgili çalışmaların günümüze kadar hız kesmeden devam ettiğini söylemek mümkündür. Bu nedenle bu çalışmada diğer disiplinler açısından müşterek lafız konusu -çalışmanın kapsamını da aşacağından- dışarıda bırakılmıştır. Ancak şu kadarını ifade etmek gerekir ki Arap dili ve tefsir ilimlerinde müşterek lafız fikıh usulüne nazaran daha kapsamlı bir olgudur. Bu alanlarda mutlak şekilde birden çok anlama delalet eden lafizların hepsi müşterek kabilindendir. Demek oluyor ki bu alanlarda müşterek lafız, eşadlılık, zıt anlamlılık, mecaz, istiare, lehçe farklılığı vb. dilsel olguların tamamını kapsar. ${ }^{12}$ Halbuki fikıh usulünde müşterek lafız, aşağıda geleceği üzere oldukça dar ve özel bir manaya sahiptir. Bunu görmek için sözlük anlamına kısaca yer verdikten sonra bir fikıh usulü terimi olarak müşterek lafzı daha yakından inceleyebiliriz.

\subsection{Sözlük Anlamı}

Müşterek kelimesi, Şe-ri-ke/yeş-ra-kü fiilinin ifti'âl babından türeyen bir isimdir. Sözlükte bir şeyin karışık olduğunu, eşit olduğunu ya da birden çok kişi arasında ortak olması durumunu ifade eder. Buna göre (اشترك الأمر) dendiğinde “iş karıştı/karmaşık bir hal aldı anlamı ortaya çıkar. O şey aralarında müşterektir (هو مشترك بينهم) ifadesi, bir şeyin birden çok sahibinin olduğunu; ortaklığa konu olduğunu anlatır. Bunun yanı sıra "umumi olma" anlamına da gelir. Örneğin ecir-i müşterek dendiğinde bir

8 Râzî, el-Mahsûl, 283.

9 İbn Rüşd, Bidâyetü'l-müctehid ve nihâyetü'l-muktesıd (Kahire: Dâru'l-Hadîs, 2004), 1/12.

10 Bk. M. Suat Mertoğlu, "Vücûh ve Nezâir", Türkiye Diyanet Vakfi İslam Ansiklopedisi (İstanbul: TDV Yayınları, 2013).

11 Konuyla ilgili yapılmış çalışmalar için bk. Sabri Türkmen, “Arapçada Çokanlamlılık ve Kur’an-1 Kerim”, Diyanet İlmi Dergi XLVI/2 (2010), 79-96.

12 Sabri Türkmen, “Arapça'da Çok Anlamlılık ve Kur'an-1 Kerim”, Diyanet İlmi Dergi, Kur'ân Özel Sayısı (2012), 540 . 
kişiye ya da bir kuruma hizmet eden ücretli değil de talep eden herkese hizmet eden kişi anlaşılır. Müşterek yol ifadesi ise herkesin kullanımına açık umumi yol demektir. Aynı meselede birden çok kişinin eşit hak veya paylara sahip olması da müşterek kelimesiyle ifade edilir. Mesela aynı kişinin terikesine eşit miktarda/payda mirasçı olanlara müşterek vâris denmektedir. Birden çok anlamı olan isimlere de müşterek isim denmektedir ki müşterekin bu manası konumuzla doğrudan ilgili olanıdir. ${ }^{13}$

Müşterek lafızların Türkçedeki karşılığı eş sesli (sesteş)/eşadlı sözcükler ve çok anlamlı kelimelerdir. Bilindiği üzere Türkçede aynı ses değerine sahip olan kelimenin farklı anlamları arasında bir ilişki bulunuyorsa buna çok anlamlılık denir. Buna karşılık anlamlar birbiriyle alakasız ise bu tür kelimelere sesteş/eşadlı sözcük denir. ${ }^{14}$ Arapçada böyle bir ayırım söz konusu olmadığından gerek çok anlamlı gerekse de sesteş/eşadlı sözcüklerin tamamı müşterekin kapsamına girer.

\subsection{Literatürdeki Yeri ve Terim Anlamı}

Bir fikıh usulü terimi olarak müşterek, fukahâ yöntemini benimseyen usulcüler tarafından vaz‘ olundukları mana bakımından lafız ayırımı içinde ele alınır. Mütekellimin usulcüler tarafından ise genelde lafız ve mananın tekliği ve çokluğu bakımından yapılan taksimde incelenir. ${ }^{15}$ Bazen de âmm veya mücmel lafız içinde işlenir. ${ }^{16}$ Müşterek lafzın fikıh usulündeki anlamı, yukarıda yer verilen sözlük anlamlarına uygun olarak farklı birkaç şekilde ortaya çıkmıştır. Bu tanımlardan bazıları şöyledir:

Şâşî, Kerhî ve Cessâs gibi erken dönem Hanefî usulcülerin müşterek tanımı, "iki veya daha çok farklı mana için vaz' olunan lafiz" şeklindedir. ${ }^{17}$ Debûsî, müşterek lafzı; "Tekdüzelik ve şümûl olmaksızın birbirinden farkh isim ve manalar ifade etmeye ihtimali olan lafızdır" şeklinde tanımlar. Farklı manalara gelen (görme organı, pınar, terazi kefesi, zimmette olmayan hazır mal) "ayn” kelimesini örnek vererek tanımdaki kayıtları şu şekilde izah eder: Müşterek lafız muhtemel manalarının hepsini aynı anda kapsamaz. Bunlardan sadece birini ifade eder, diğerleri ise dışarıda kalır. ${ }^{18}$

13 el-Ferâhîdî Halîl b. Ahmed, Kitâbu'-'ayn, thk. Mehdî el-Mahzûmî - İbrahim es-Sâmurâî (Beyrut: Mektebetü'l-Hilâl, 1988), 5/294; İbn Manzûr, Muhammed b. Mükerrem, Lisânu'l-'Arab (Beyrut: Dâr Sâdır, 3. Baskı, 1993), 10/449; Ahmed b. Muhammed Feyyûmî, el-Misbâhu'l-münîr fi garibi'ş-şerhi'l-kebîr (Kahire: Dâru'l-Hadîs, 2003), 187.

14 Ömer Acar, Anlam Değişmeleri Işı̆̆ında Kur'an'da Yeni Anlam Kazanan Kelimeler (Bursa: Emin Yayınları, 2016), 99.

15 Ebü'l-Hüseyn Basri, el-Mu'temed fi usûli'l-fikh, thk. Halil el-Mîs (Beyrut: Dâru'l-Kütübi'l-ilmiyye, 1403), 1/299; Gazzâlî, el-Müstasfâ, 2/141.

16 Ebu İshak Şîrâzî, el-Luma'fi usûli'-fikh, thk. Eymen Salih Şâbân (Kahire: el-Mektebetü’t-Tevfîkıyye, 2013), 113.

17 Şâşî, Usûlü'ş-Şâşî (Beyrut: Dâru'l-Kitâbi'l-Arabî, ts.), 36; Ebu Bekr er-Râzi Cessâs, el-Füsûl fi'l-usûl (Kuveyt: Vizâretü'l-evkâfi'l-Kuveytiyye, 1994), 1/76.

18 Ebû Zeyd Debûsî, Takvîmü'l-edille fi usûli'l-fikh, thk. Halil Muhyiddin el-Mîs (Beyrut: Dâru'l-Kütübi'l-ilmiyye, 2001), 94. 
Pezdevî̀nin tanımına göre müşterek lafız; "birbirinden farklı birkaç manadan veya birkaç isimden birine ihtimali olan ve bunlardan sadece birinin kast edilmiş olduğu lafizdır". ${ }^{19}$ Serahsî, müştereki; "aynı anda hepsini kapsayacak şekilde değil de her birinin tek başın a murat edilmiş olma ihtimali olan birden çok isim ve manayı ifade eden her lafizdır" şeklinde tanımlar. ${ }^{20}$ Semerkandî̀ye göre "müşterek, birden çok manaya eşit derecede ihtimali olan lafizdır." Ondan gelen bir başka tanıma göre müşterek, "farklı veya zıt manaları aynı anda kapsayan ve anlamı sözün sahibi tarafindan bilinip işiten/muhatap kişi tarafindan bilinmeyen lafızdır." Bu sebeple müşterekin mücmelin (kapalı lafızların) bir çeşidi sayıldığını belirtir. Semerkandî, bunu ifade etmek için konuyu "her müşterek mücmeldir, fakat her mücmel müşterek değildir" şeklinde formüle eder. ${ }^{22}$ Nesefînin müşterek tanımı ise şöyledir: "Mahiyetleri farkh olan birden çokferdi bedel yoluyla [aynı anda değil de birbirinin alternatifi olarak] kapsayan lafizdır."23

Müştereki "ilk baştan iki veya daha çok farklı mana için konulan lafizdır" şeklinde tanımlayan Râzi, özellikle hakikat ve mecaz olarak farklı manalara gelen lafızların müşterek kapsamında olmadığına dikkat çeker. ${ }^{24}$ Mâlikîler'den Karâfî̀nin tanımına göre müşterek, "iki ve daha çok manadan her biri için ayrı ayr konulmuş lafiz"dır. ${ }^{25}$ Sadru'ş-şerîa ve Teftezânî de "birden çok vaz' ile çok mana için vaz' olunan lafiz" şeklinde buna yakın bir tanim yaparlar. ${ }^{26}$

Erken dönemlerde yapılan tanımlamalardan hareketle sonraki dönem usulcüler müşterek lafzı, "her biri ayrı vaz' ile olmak üzere iki veya daha çok manaya gelen lafiz" olarak veya ifadeler değişse de bu manayı ifade edecek şekilde tanımlamışlardır. ${ }^{27}$ Çoğu çağdaş araştırmacının da benimsediği tanım budur. ${ }^{28}$ Bu tanımlardan hareketle müşterek lafzın üç özelliği öne çıkmaktadır. Bunlar; iki ve daha çok hakiki mana için kullanılması, her bir mana için ayrı ayrı konulmuş olması ve bu manaları birbirinin

19 Fahrulislam Pezdevî, Kenzü'l-Vusûl ilâ márifeti'l-usûl, thk. Sâid Bekdâş (Beyrut: Dâru'l-Beşâiri'l-İslâmiyye, 2014), 98.

20 Şemsü'l-eimme es-Serahsî, Usulü's-Serahsî (Beyrut: Dâru'l-Marife, ts.), 1/126.

21 Semerkandî, Mizânü'l-usûl, 1/92.

22 Semerkandî, Mizânü'l-usûl, 1/340-341.

${ }^{23}$ Ebü'l-Berekat Nesefî, Menârü'l-envâr; Metnü'l-Menâr fî usûli'l-fikh, thk. Ahmed Abdullah Abdurrahman esSa'dî (Kahire: Dâr Sa'duddîn, 2010), 98.

24 Râzî, el-Mahsûl, 261.

25 Şihabuddin Karâfî, Şerhu Tenkîhi'l-füsûl, thk. Taha Abdurrauf Sa‘d (Kahire: Şeriketü’t-tibâe el-Fenniyye, 1973), 29.

26 Sa'düddîn Teftezânî, Şerhu't-Telvîh ale't-Tavdîh (Misır: Mektebet Subeyh, ts.), 1/56.

27 Teftezânî, Şerhu't-Telvîh ale't-Tavdîh, 1/56; Mehmed Efendi Molla Hüsrev, Mirkâtü'l-vusûl ilâ ma'rifeti'l-usûl fi usûli'l-fikh, thk. İlyas Kaplan (Beyrut: Dâru'l-Kütübi'l-ilmiyye, 2012), 86; Muhammed b. Ali Şevkânî, İşâdül-fuhûl ilâ tahkiki'l-hak min ilmi'l-usûl, trc. Ahmed Azzo İnâye (Beyrut: Dâru'l-Kitâbi'l-Arabî, 1999), 1/57. Diğer tanımlar için bk. Mahbûb Kahtân, “Delâletü'l-müşterek inde’l-usûliyyin”, Mecellet Külliyeti'şşerîa, 3 (2012), 4-5.

28 Abdülvehhab Hallâf, i̇lmü usûli'l-fikh (Kahire: Dâru'l-Hadîs, 2003), 205; Muhammed Ebû Zehra, Usulü'l-fikh (Kahire: Dâru'l-Fikr, 2006), 155; Salih Muhammed Edîb, Tefsîru'n-nusûs, 4. Bs (Beyrut: el-Mektebü'l-İslâmî, 1994), 2/134. 
alternatifi olarak kapsamasıdır. Bu özellikleri sebebiyle âmm ve mutlak lafızdan ayrılmaktadır. Çünkü âmm lafız, kapsamına giren bütün fertleri istisnasız şekilde kapsarken, müşterek sadece birini ifade eder. İşiten kişi açısından her zaman bilinmese de müşterek lafizla kastedilen mana tektir ve bellidir. Oysa mutlak lafızda mana bir ise de bu muayyen değil, herhangi bir ferttir. ${ }^{29}$ Görüldüğü üzere müşterekin tanımları, lafzın muhtemel bütün manalarının aynı anda kastedilmiş olup olmayacağının imkânı ile ilgili ortaya çıkan tartışmalardaki yaklaşımlar doğrultusunda şekillenmiştir. Demek oluyor ki müşterek lafzın en temel problemlerinden biri müşterekin umumu meselesidir.

Bu noktada lafızlarda iştirakin, isimlerde, fiillerde ve harflerde görüldüğünü belirtmek gerekir. Söz gelimi Arapçada "cariye" hem gemi hem de hür olmayan kadın anlamına gelen bir isimdir. Yine "As'ase (عسعس)" fiilinin gelmek ve gitmek olmak üzere iki anlamı vardır. Min (من) harf-i ceri ise ba'ziyet ve ibtidâ olmak üzere iki farklı anlamda kullanılmaktadır. ${ }^{30}$

\section{Müşterek Lafzın Ortaya Çıkış Sebebi}

Dilde asıl olan her lafzın tek bir manayı ifade etmesidir. ${ }^{31}$ Buna rağmen birtakım sebeplere bağlı olarak birden çok mana ifade eden müşterek lafizlar meydana gelmiştir. Bu sebeplerin başında Arap kabileleri arasındaki farklılıklar gelir. Aynı lafız iki kabile tarafından farklı manalarda kullanılabilir. Hatta bazen bu iki mana arasında herhangi bir alaka da bulunmaz. Böylece bir lafız iki farklı mana için vaz‘ edilmiş olur ve sonraki nesillere vaz‘ edenin farklılı̆̆ına işaret edilmeksizin her iki manada kullanılarak aktarilır. ${ }^{32}$

İkinci bir sebep ise bir lafzın iki mana arasında ortak bir manayı ifade etmek için vazedilmiş olmasıdır. Örneğin "kur" lafzı, hayız ve tuhr lafızlarının ifade ettiği iki ayrı mana arasında ortak bir manayı ifade etmek için konulmuştur. Zira bu lafız sözlükte belirli bir durumla ilgili zaman devresi (periyot) anlamına gelir. İște hayız ve tuhr belirli zaman dilimlerinden oluştuğu için bu anlama gelen "kur"' lafzı, her ikisinin ifade ettiği manalar arasında ortak bir manayı (periyot) ifade etmek için kullanılmıştır. Ancak zamanla bu iki manadan her biri için elverişli hale gelmiştir. ${ }^{33}$

Müşterek lafzı meydana getiren bir başka sebep de bir lafzın mecaz anlamının yaygınlaşarak sonraki nesillere hakikat olarak aktarılmasıdır. Şöyle ki; bir lafız önce bir mana için konulmuş olur. Sonra aynı lafız bir tür alakadan dolayı mecaz yoluyla

\footnotetext{
29 Semerkandî, Mizânül'-usûl, 342.

30 Dirşevî, “Mezâhibü'l-Usûliyyîn fi isti 'mâli'l-müşterek fî meânîhi meân”, 230.

31 Râzî, el-Mahsûl, 275; Bedrüddîn Zerkeşî, el-Burhân fi usûli'l-fikh (Amman: Dâru'l-Kütübi, 1994), 2/381.

32 Semerkandî, Mizânül'-usûl, 1/344; Râzî, el-Mahsûl, 265.

33 Zekiyyuddin Şaban, İslam Hukuk İlminin Esasları, trc. İbrahim Kâfi Dönmez (Ankara: Diyanet Vakfi Yayınları, 30. Bask1, 2018), 468.
} 
başka bir manada kullanılır. Zamanla bu lafzın mecazi anlamdaki kullanımın yaygınlaşması sebebiyle bu manada örfî hakikat haline gelir. Böylece bu lafzın her iki manası sonraki nesillere hakikat olarak aktarılır. ${ }^{34}$ Buradan hareketle bazı müellifler, müşterek lafzın aynı dildeki manalarından sadece birinin aslî mana olduğunu kaydederler. ${ }^{35}$ Bazı kaynaklarda "salat" sözcügünde olduğu gibi bir lafzın dilde ve ıstılahta farklı manalar için vazedilmesi de iştirakin sebepleri arasında sayılmaktadır. ${ }^{36}$ Arap dilbilimcilere göre çok anlamlılı̆̆ın iki sebebinden daha söz edilir. Bunlar; yakınlık (mücâvere) ve benzerlik (müşâbehe) olgularıdır. ${ }^{37}$

Sebebi ne olursa olsun müşterek lafız olgusu her dilde inkâr edilemez bir gerçeklik olarak karşımıza çıkmaktadır. Neredeyse bütün dünya dillerinde birden çok anlamı olan sözcükler mevcuttur. Esasında çok anlamlılık, hemen her dilde bir dil sorunu olarak üzerinde durulan bir husustur. Ne var ki Arap dilinde bu sorun daha belirgindir. Dilin yapısı ile Kitap ve sünnet metinlerinin Arapça olması bunun en temel sebepleri arasında sayılabilir.

\section{Müşterek Lafzın Hükmü}

Fıkıh usulünde müşterek lafzın hükmünden kasıt, böyle bir lafızla karşılaşıldığında fakihin ve/veya usulcünün hareket tarzıdır. Çünkü gerek naslardan hüküm çıkarmak gerekse de naslarla amel etmek nassın manasına göre şekillenir. Müşterek lafızda olduğu gibi nassın bir veya daha çok manaya gelmesi o nassın delaleti konusunda bir kapalılık olduğunu gösterir. Şu hâlde nassı anlamak ve gereği ile amel etmek için bu kapalılık giderilinceye kadar beklemek (tevakkuf) gerekir. Ancak kapal1lığın giderilmesi için lafzın ifade ettiği manayı araştırmak şarttır. ${ }^{38}$ Aksi takdirde nassın manasını anlamak ancak sözün sahibinin beyanıyla mümkün olabilir. Bu durumda lafız müşterek olmaktan çıkar ve mücmel olur. Demek oluyor ki müşterek lafız ya mücmel olur ya da muhtemel manalarından birine hamledilip müevvel lafza dönüşür. ${ }^{39}$ Yaygın kanaat bu şekilde olmakla beraber -aşağıda geleceği üzere- müşterekin umumunu kabul edenler arasında birkaç isim karinelerden soyut olan müşterek lafzın tüm manalarına hamledileceği iddiasındadır. ${ }^{40}$

Fıkıh usulü bilginlerine göre lafızlarda asıl olan iştirakin olmamasıdır. Bu nedenle bir lafızda müşterek olma ve olmama durumu söz konusu ise ikincisinin tercih edilmesi gerektiği ifade edilir. Çünkü lafızlarda tek anlamlılı̆̆ın genel ve yaygın

\footnotetext{
34 Basri, el-Mu'temed, 1/17; Semerkandî, Mizânü'l-usûl, 339; Ebû Zehra, Usulü'l-fikh, 155; Hallâf, İlmü usûli'lfikh, 206; Muhammed Edîb, Tefsîru'n-nusûs, 2/136-137; Şaban, İslam Hukuk İlminin Esasları, 467-468.

35 Zerkeşî, el-Burhân, 2/379.

36 Kahtân, "Delâletü'l-müşterek inde'l-usûliyyin”, 10.

37 Türkmen, “Arapça'da Çok Anlamlılık ve Kur'an-1 Kerim”, 534.

38 Cessâs, el-Füsûl fi'l-usûl, 1/77; Şemsü'l-eimme Serahsî, el-Mebsût (Beyrut: Dâru'l-Ma'rife, 1993), 1/162; Nesefî, el-Menâr, 98; Molla Hüsrev, Mirkâtü'l-vusûl, 86.

39 Nesefî, el-Menâr, 98; Zerkeşî, el-Burhân, 2/381; Ferhat Koca, "Müşterek”, Türkiye Diyanet Vakfi İslam Ansiklopedisi (İstanbul: Türkiye Diyanet Vakfi Yayınları, 2006).

40 Râzî, el-Mahsûl, 278.
} 
olduğu hususu, tümevarım yöntemiyle ispat edilen bir durumdur. ${ }^{41}$ Aynı şekilde muhtemel manalardan birini ifade ettiği kuvvetle muhtemel ise iştirak söz konusu değildir. Farklı manaları ifade etme biçimi lafzın birden çok manayı kapsaması şeklinde olması halinde de iştirakten söz edilemez. Çünkü kapsayıcılıkta eşitlik yoktur. Buna göre bir lafız, iki veya daha çok manayı ayrı ayrı ve eşit şekilde ifade etme ihtimali bulunuyorsa müşterektir. Hanefî usulcü Serahsînin ifadesiyle söyleyecek olursak lafzın müşterek olduğuna hükmetmek için öncelikle siygasına bakarak birden çok mana için vaz‘ olunmuş olduğu tespit edilmelidir. ${ }^{42}$

Lafzın müşterek olduğu anlaşılırsa önce muhtemel manalarından hangisinin kastedildiğini tespit etmek gerekir. Bunun için de evvelemirde iştirakin mahalli olan lafzın taşıdığı manalara bakılır. Bunlardan biri dildeki anlam diğeri terim anlamı ise aksi yönde bir karine bulunmadıkça terim anlamının kastedildiğine hükmedilir. Söz gelimi "salât" kelimesinin sözlük anlamı dua, terim anlamı ise namazdır. Şu hâlde naslarda geçen "salât" kelimesinin namaz olarak anlaşılması esastır. Ancak bunun aksini gösteren bir karine varsa o zaman sözlük anlamı dikkate alınır. Nitekim Ahzab suresi 56. ayette geçen "salât" kelimesi "anma/dua" olarak anlaşılmıştır. Burada lafzın fiil kalıbında gelmiş olması ve Allah'ın ve meleklerin de Nebî̀ye (a.s.) salât ettiği şeklindeki ifadelerden hareketle murat edilen mananın namaz olmadığı anlaşılmaktadır. Eğer bir lafız terim anlamı söz konusu olmadan iki veya daha fazla mana arasında müşterek ise içtihat yoluyla hangi manada kullanıldı̆̆ını tespit etmek gerekir. Bu çerçevede önce lafzın siygası üzerinde bir tahlil yapilır. Daha sonra muhtemel manalarından birini tercih etmek için teşriin maksatları doğrultusunda emareler, karineler ve deliller araştırılır. Bu deliller lafzî, aklî veya naklî olabilir. ${ }^{43}$

Müşterek lafızla birlikte gelen karine/delil dört farklı şekilde görülebilir. (1) Ma-

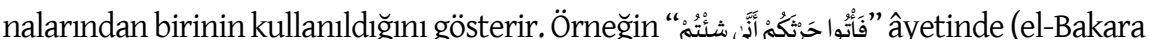
2/223) lafzı nasıl ve nerede anlamlarına gelen (keyfiyet ve mekân) müșterek bir lafizdır. Ancak bir önceki âyette (el-Bakara 2/222) "iyice temizlendiklerinde onlara Allah'in emrettiăi sekilde vaklasın" ifadesinden buradaki أنى lafzının nasıl (keyfiyet) manasında kullanıldığını göstermektedir. (2) Bazı manalarını ilga eder. Böylece mülga dışındaki mana(lar)a hasredilmiş olur. Söz gelimi bir kadına “kur' günlerinde namazı bırak/ دَعَى " dendiğinde tuhr/temizlik dönemi ilga edilmis olur. (3) Birden çok manada kullanıldığına delalet eder. Bu umumu'l-müsstereki kabul edenlere göredir. "Berrâk göz/عَافََّ" sözü bövledir. Cünkü saflık/berrakllk hem görme duvusu olan gözün hem de pınar anlamındaki gözün sıfatı olabilir. (4) Tüm manalarının ilga edildiğini gerekli kılar. Bu durumda lafız ifade ettiği manaların hakikatinden hareketle mecazi anlama hamledilir. $^{44}$

41 Râzî, el-Mahsûl, 275; Zerkeşî, el-Burhân, 2/382.

42 Serahsî, el-Mebsût, $1 / 163$.

43 Hallâf, İlmü usûli'l-fikh, 205; Muhammed Edîb, Tefsîru'n-nusûs, 2/139.

44 Zerkeşî, el-Burhân, 2/383-384. 
$\mathrm{Bu}$ aşamada bazen tercihi gerektiren birden çok delil ve karinenin bulunması söz konusu olabilmektedir. Her zaman olmasa da bu durumda lafzın manası konusunda farklı tespitlerin yapıldığı görülmektedir. Böylece müşterek lafzı içeren delilden çıkarılan hükümde farklı yaklaşımlar sergilenmektedir. Çünkü aşağıdaki örneklerde görüleceği üzere delillerden veya karinelerden birini tercih etmek tamamen içtihadi bir çabanın ürünüdür.

Usul bilginleri “Boşanmış kadınlar kendi kendilerine üç kur' beklerler..." geçen kur' kelimesinin hangi manada kullanıldı̆̆ı hususunda ihtilaf halindedirler. Müşterek bir lafız olan kur' kelimesi hem hayız hem de iki hayız arasındaki tuhr (temizlik) anlamına gelir. Buna göre âyette boşanan bir kadının bekleyeceği sürenin hesaplanmasında temizlik döneminin mi yoksa hayız döneminin mi dikkate alınacağ hususu kapalıdır. Hanefî ve Hanbelî mezheplerinde âyette geçen kur' lafzıyla kastedilen hayız iken Mâlikî ve Şâfiîler'e göre temizliktir (tuhr). ${ }^{46}$

Hanefî usulcüler, âyette geçen "üç" kelimesinin hâs bir lafız olmasından hareketle kur' lafzının hayız manasına geldiğini tespit ederler. Çünkü onlara göre hâs lafız, bilinen tek bir manayı ifade etmek için konulmuş bir lafız olup manaya delaleti kesin ve açılamaya ihtiyaç duymayacak kadar açıktır. ${ }^{47}$ Öyleyse kadının iddetinde sayacağı kur’un tam olarak üç olması gerekir. Sünnî talaka göre kadının temizlik döneminde boşanması gerektiğine göre üç sayısı tam olarak ancak hayız döneminin sayılmasıyla gerçekleşir. Temizlik döneminin dikkate alınması halinde beklenecek kur' sayısı üçten az veya fazla olacaktır. Şöyle ki kadın boşanırken içinde bulunduğu temizlik dönemini sayacak olursa boşamanın meydana geldiği ana kadar geçen zaman üç kur'dan eksilmiş olacağından tam üç kur' beklememiş olacaktır. İçerisinde bulunduğu dönemi saymayacak olursa boşama meydana geldikten ilk hayı dönemine kadar geçen zamanı fazladan beklemiş olacaktır. Böylece iddet süresi üç kur'dan fazla olarak beklenecektir. Ayrıca iddet yükümlülüğünün neslin karışmaması için boşanan kadının önceki kocasından hamile olup olmadığının anlaşılması amacına yönelik bir tedbir olduğuna dikkat çekerek bunun ancak hayızla anlaşılabileceği iddiasındadırlar. Hanefî fukahâsının bir başka dayanağı ise, iddetle ilgili olan diğer naslarda iddetin hayızla ilişkilendirilmesidir. Bunlar arasında Talâk suresinin 4. âyetinde "...hayızdan kesilmiş kadınlar" ve “...henüz hayız görmemiş olanlar" ifadeleri ile "Hayız günlerinde namazı bırak"48 ve "Cariyenin iddeti iki hayızdı" "49 rivayetlerine işaret ederek kur' kelimesine neden hayız manası verilmesi gerektiğini temellendirirler. ${ }^{50}$

${ }^{45}$ Kur'an Yolu (Erişim 27 Aralık 2019), el-Bakara 2/228.

46 İbn Rüşd, Bidâyetü'l-müctehid, 3/108.

47 Nesefî, el-Menâr, 73-74.

48 Ali b. Ömer Dârekutnî, es-Sünen, thk. Şuayb Arnâut v.dğr. (Beyrut: Müessetü’r-Risâle, 2004), 1/384.

49 Ebû Abdillah b. Enes Mâlik, el-Muvatta', thk. Muhammed Mustafa el-Azamî (Ebû Dabî: Müesseset Zâyid b. Sultan, 2004), “Talak”, 18.

50 Osman b. Ali Zeylaî, Tebyînü'l-hakâik (Kahire: el-Matbaatü'l-kübrâ el-Emîriyye, 2. Bask1, 1313), 3/26-27; Ebü'l-Fazl Mecdüddin Abdullah b. Mahmûd b. Mevdud Mevsilî, el-İhtiyâr li tąlîli'l-Muhtâr, thk. Muhammed Adnan Derviş (Beyrut: Daru'l-Kütübi'l-ílmiyye, 1996), 3/174. 
Mâlikî ve Şâfiî usulcüler ise üç farklı karineden hareketle kur' kelimesinin tuhr manasına geldiğini ifade ederler. Birincisi; sayının temyizi kuralıdır. Şöyle kibir nahiv kuralı olarak üç ile on arası sayılarda müzekkerlik ve müenneslik açısından temyiz sayıya zıt şekilde gelir. Bu kurala göre Bakara 228. âyette üç lafzı müennes (ثلاثة) olduğuna göre temyizi müzekker olan tuhrdur. İkincisi; Arapça'da kur' kelimesinin dilde 'toplama ve hapsetme' manasına geldiğinden hareketle "kanın toplandı̆̆ı/hapsedildiği dönemin de temizlik dönemi olduğunu ifade ederler. Üçüncüsü; hayız manasına gelen kur' (قرء) kelimesinin çoğulu akrâ' (أَقْرَاء) şeklinde gelir. Âyette geçtiği üzere kurû'

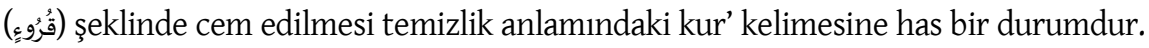
Bu aklî delillerin yanı sıra Hz. Aişe'den gelen "kur'lar ancak temizlik dönemleridir" ${ }^{51}$ rivayeti de bir başka dayanaklarıdır. ${ }^{52}$

Buradaki ihtilafın semeresi iddetin ne zaman tamamlanacağı noktasında görülmektedir. Kur' lafzına hayız manasını verenlere göre iddet üçüncü hayız döneminin sona ermesiyle tamamlanır. Temizlik (tuhr) anlamı verenler ise üçüncü hayzın başlamasıyla tamamlanacağı görüşündedirler. Bu ise kocanın ric'at hakkını, eşlerin birbirlerine mirasçı olması ve kadının başkasıyla evlenebilmesi gibi önemli hususların hükmünü belirlemede etkin rol oynar.

Hanefî usul bilginlerine göre müşterek lafzın muhtemel manalarından hangisinin murat edildiği anlaşılmadıkça tevakkuf edilir. Bu durumda kural; tevakkuf edip kendisiyle kastedilen mananın hak olduğuna inanmaktır. Ancak bu, müşterek lafzın manalarından birini tercih etmeyi gerektiren delil veya karine bulunmaması halindedir. ${ }^{53}$ Detayları aşağıda geleceği üzere İmam Şâfiî ve onunla aynı görüşte olan az sayıdaki usulcüye göre ise lafzı tüm manalarına hamletme imkânı varsa böyle yapılır. Bu mümkün değilse tevakkuf edilir.

Netice itibariyle müşterek lafzın muhtemel manalarından birini tercih etmek mümkün olmazsa tevakkuf edilir. Manalarından biri tercihe şayan bulunursa bu manasıyla amel etmek gerekir. Çünkü bu durumda lafız müevvel (tevil edilmiş) olur. Müevvel lafzın hükmü ise zahir lafızla aynıdır. ${ }^{54}$ Yani hata ihtimalini göz önünde bulundurmak kaydıyla gereğiyle amel etmek gerekir. Ancak bu ihtimal sebebiyle müevvel lafzın bilgi derecesinin haber-i vahid hükmünde olduğu ifade edilir. ${ }^{55}$ Çünkü manalarından birine hamledilmeden önce müşterek, bir yönüyle zahir bir yönüyle kapalı lafızdır. Şöyle ki muhtemel manalarından başka bir şey kastedilmemiş olması açısından zahir, bu manalarından hangisini ifade etmek için kullanıldığının bilinmemesi yönüyle mücmeldir. ${ }^{56}$

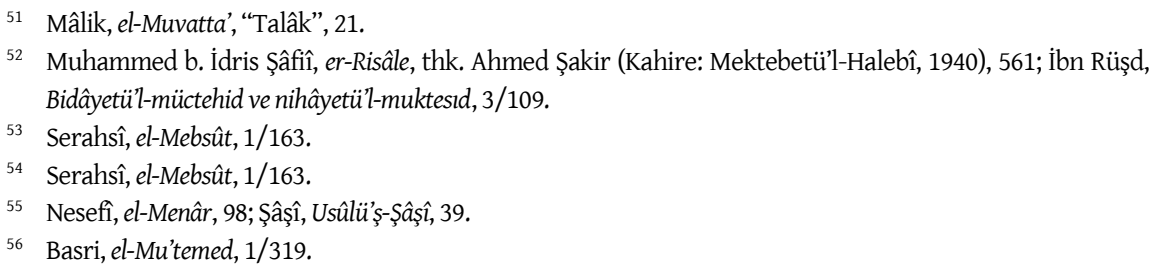




\section{Müşterek Lafzın Umumu}

Müşterek lafzın umumiliği meselesi, fikıh usulü literatüründe umûmü'l-müşterek tamlamasıyla ifade edilir. Usûl bilginleri bununla müşterek lafzın kapsamına giren manaların hepsinin veya en azından ikisinin tek bir kullanımda ve aynı anda kastedilmiş olduğunu ifade ederler. ${ }^{57}$ Bu nedenle siyganın tekrarlanması, konuşanın, yerin veya zamanın değişmesiyle müşterekin bütün manalarını ifade etmesi bu kabilden değildir. Çünkü söz konusu hallerden birinin değişmesi durumunda müşterekin farklı anlamlarda kullanılabileceği konusunda usul alimleri hemfikirdir. ${ }^{58}$

Usûl literatüründe konuyla ilgili temelde üç yaklaşımdan söz edilebilir. Hemen belirtmek gerekirse bu tartışma lafzın ifade ettiği manaların hepsine delalet etmesinin mümkün olması durumundadır. Aksi takdirde yani lafzı birden çok manaya hamletme imkânı yoksa -manaların birbirine zıt olması gibi- manalarından biri tercih edilene kadar beklemenin gerekliliği konusunda fıkıh usulcüleri ittifak halindedirler.

\subsection{Müşterekin Umumunu Caiz Görmeyenler}

Bir grup usulcü, müşterek lafzın umumiliğini; yani aynı anda birden çok manayı ifade edebileceğini kabul etmezler. Onlara göre aynı anda müşterek lafzın ifade ettiği manalardan sadece biri kastedilmiştir. Hanefîler' in büyük çoğunluğu, Şâfiîler'den bir grup usulcü ve Mutezile'den Ebû Ali el-Cübbâî (öl. 303), Ebû Hâşim (öl. 321) ve Ebü'lHüseyn el-Basrî (öl. 436) gibi isimler bu görüştedir. ${ }^{59}$

Hanefîler, müşterek lafzın kapsamına giren isim veya manaların birbirinden farklı olduğuna dikkat çekerek müşterek lafzın umumiliğini şu izahlarla reddederler: Bu lafzın "müşterek" adıyla anılıyor olmasının sebebi, birden çok ismin ve mananın bu lafızda ortak oluşudur. Ortaklık ise eşitliği ifade eder/gerektirir. Buna göre bu isim ve manalar eşit şekilde bu lafzın kapsamına girmiştir ve aralarını cem' etmek (birleştirmek) de mümkün değildir. Bu manalardan birinin diğerlerinden öncelikli (evlâ) olması da söz konusu değilse bu lafızla kastedilen mana meçhul olur. Böylece müşterek lafiz mücmel konumunda olur. ${ }^{60}$

Debûsî, bu yaklaşımı temellendirmek üzere iddet süresini ifade etme maksa-

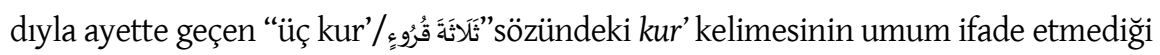
konusunda ümmetin icmâ ettiğinin altını çizer. Bu lafızla hayız veya temizlik (tuhr) manalarından birinin kastedildiğini kaydeder. Pezdevînin argümanı ise dildeki kullanım açısından emsal niteliğindeki ألصريم lafzıdır. Bu lafız hem geceyi hem de sabahı ifade etmek için konulmuştur. Dolayısıyla kullanıldığı yerde hem sabah hem de gece

57 Teftezânî, Şerhu't-Telvîh ale't-Tavdîh, 1/124.

58 Ahmed Sudirman Abbas, “Mevkıfü'l-fukahâ fi'l-lafzi'l-müşterek ve eserehü fi'l-fikhi'l-İslâmî”, Ahkam Jurnal Hukum Islam 36/1 (Ocak 2016), 132.

59 Basri, el-Mu'temed, 1/300; Ebû İshâk Şîrâzî, Şerhu'l-Luma' fì usûli'l-fikh, thk. Abdülmecid Türkî (Beyrut: Daru'l-Ğarbi'l-İslâmî, 1998), 1/456; Gazzâlî, el-Müstasfâ, 2/141; Nesefî, el-Menâr, 98; Molla Hüsrev, Mirkâtü'l-vusûl, 86; Leknevî, Fevâtihu'r-rahamût, 1/165.

60 Cessâs, el-Füsûl fi'l-usûl, 1/76; Debûsî, Takvîmü'l-edille, 95. 
anlamında kullanılmış olamaz. ${ }^{61}$ Aynı şekilde kendisi azatlı bir köle olan ve azatlı kölesi de bulunan bir kimsenin "malımın 1/3'nü mevlâlarıma bırakıyorum" şeklindeki vasiyeti, hangi mevlâsını kastettiğini açıklamaz ise geçersizdir. Çünkü mevlâ lafzı hem azat eden hem de azat edileni hakiki anlam olarak ifade eder. Bu iki mana birbirine zıt olduğundan aynı anda kastedilmiş olamaz. ${ }^{62}$

Gazzâli, Şâfiî mezhebinde İmam Şâfiî̀ ve Kadı Abdülcebbâr dışında umûmü'l-müştereki kabul eden başka kimsenin olmadığını ifade etmektedir. Ona göre Araplar, bu lafızları manalarından her birinin diğeri yerine kullanılabilecek şekilde ayrı ayrı vaz‘ etmişlerdir. Bütün manaları aynı anda kullanılacak biçimde vaz‘ edilmiş değildir. Müşterek, ifade ettiği manaların hepsine nispeti bakımından eşittir. Ancak gerçekte bu lafız vaz' olunduğu anlamlardan sadece birini ifade etmek üzere kullanılır. Öyle ki bu anlam, başka bir manaya ihtimali olmayacak şekilde belirli ve tektir. Bu, bir fiilin farklı şekillerde meydana gelmesinin imkanına benzer. Tıpkı muayyen bir namazın Hz. Peygamber'in (s.a.v.) fiillerinden öğrenilmesinde olduğu gibi. Bu namaz hakikatte muayyen olmakla birlikte bizim açımızdan farz, nafile, eda, kaza, öğlen, ikindi veya yatsı namazı olması mümkündür. Burada farklı ihtimallerin eşdeğer olması, müşterekin umumiliği yanılgısına yol açmamalıdır. Yani ihtimal çok olsa da kastedilen tektir. ${ }^{63}$

$\mathrm{Bu}$ yaklaşıma sahip olan usul bilginlerinin özellikle vurguladıkları husus, müşterek lafzın ifade ettiği manalar için ayrı ayrı vazedilmiş olmasıdır. Şayet bütün manalarını ifade etmesi için konulmuş olsaydı umumu da caiz olurdu. Söz gelimi kur' kelimesi birbirinden bağımsız şekilde bir kere hayız anlamı için bir kere de tuhr anlamı için vazedilmiştir. Aynı anda hayız ve tuhr manalarına gelecek şekilde konulmuş olsaydı bu şekildeki kullanımı da mümkün olurdu. Ne var ki bu durumda kur' kelimesinin anlamı, hayız+tuhr şeklinde ortaya çıkardı. Ancak hükmün bu şekilde olmadığı bilinmektedir. ${ }^{64}$ Öte taraftan sahabe nesli, kur' lafzına yükledikleri manada farklı yaklaşımlara sahip olsalar bile manalarından birini ifade ettiği konusunda ittifak halindedirler. Onlardan kur' lafzını her iki manasına hamleden olmamıştır. Dolayısıyla bu durum "bir köle azat edin" emrinde olduğu gibi mutlak lafzın manaya delaletine benzemez. Köle lafzında iștirak yoktur, mutlak anlatım vardır. İștirakin örneği erkeği ve kadını kapsayan şahı//kişi kelimesidir. "Bir kişi gördüm” cümlesinde bunun hem kadın hem de erkek olması nasıl mümkün değilse müşterek lafızların hepsinde durum aynidır. ${ }^{65}$

Bu izaha hayız+tuhr değil de ikisi kastedilmiş olabileceğinden ikisinden birinin tercih edilmesi şeklinde itiraz getirilebilir. Dolayısıyla iddet bekleyen bir kadın hayız veya tuhrdan birini seçerek iddetini sayabilir. Ya da hayız ve tuhrdan toplamda üç kur' tamamlansın şeklinde anlaşılabilir. Tıpkı "bir köle azat edin" emrinde olduğu gibi, kişi

61 Pezdevî, Kenzü'l-Vusûl, 98.

62 Cessâs, el-Füsûl fil-usûl, 1/77; Şâşî, Usûlü'ş-Şâşî, 39.

63 Gazzâlî, el-Müstasfâ, 2/141-142.

64 Basri, el-Mu'temed, 1/303.

65 Dirşevî, “Mezâhibü'l-Usûliyyîn fi isti ‘mâli'l-müşterek fî meânîhi meân”, 240. 
lafzın kapsadığı manalardan birini tercih etmekte serbest kalsın denilebilir. Ne var ki müşterekin umumu problemi, esas itibariyle lafzın birden çok manada kullanılmak üzere vazedilmiş olması imkânına ve gerçeğine dayanır. Yukarıda geçtiği üzere müşterek, dilde ayrı ayrı birkaç defa farklı manalar için vaz edilmiş olsa da bu manaların hepsini aynı anda ifade edecek şekilde vazedilmediği açıktır. Bu nedenle sözün sahibi açısından müşterek lafızlardan kastedilen mana tektir ve bunun tespiti için gayret sarf etmek esastır. Şu hâlde müşterek bir lafzın hangi manada kullanıldığı muhatabın tercihine bırakılacak bir mesele değildir.

\subsection{Müşterekin Umumunu Kabul Edenler}

Esasında usulcülerin çoğuna göre müşterek lafızda asıl olan manalarından sadece birinin ifade edilmesidir. Bununla birlikte Mâlikiler, İmam Şâfiî ile birlikte bir grup Şâfiî, Hanbelîler, Bâkillânî (öl. 403/1013), Kâdı Abdülcebbâr (öl. 415/1025) gibi bazı ilim adamları bunun mümkün olabileceği görüşündedirler. ${ }^{66}$ Bazı müellifler Hanefî mezhebinden Ebû Yusuf ve İmam Muhammed'in de bu görüşte olduğunu kaydederler. ${ }^{67}$ Bunlar arasında İmam Şâfiî̀nin bu konudaki yaklaşımı dikkat çekicidir. Ona göre müşterek lafız, ifade ettiği tüm manalar açısından açıktır (zahir). Bu yüzden tek bir manayı ifade ettiğini gösteren bir karine bulunmadıkça bütün manalarına hamledilmesi gerekir. Çünkü bu durumda manalarından birini diğerlerine tercih etmek için bir gerekçe bulunmadığından ihtiyatlı olanı budur. Bu görüş, Bâkıllânîye de nispet edilir. ${ }^{68}$

Bu yaklaşıma göre umumü'l-müşterek caiz olduğundan müşterek lafız, ifade ettiği manaların hepsine aynı anda delalet edebilir. Bu görüşün arka planında müşterek lafzı umum bildiren (âm) lafızlar kabilinden görmeleri bulunur. Şöyle ki âm lafız nasıl ki kapsadığı bütün fertlerine aynı anda delalet ediyorsa müşterek de muhtemel manalarının hepsini aynı anda ifade edebilir.

$\mathrm{Bu}$ gruptakilerin yaklaşımlarını temellendirmek üzere naslardan birçok örneği delil olarak sundukları görülür. ${ }^{69}$ Hac suresi 18. âyette geçen secde kelimesinin kullanımı bunlardan biridir. Secde (sücûd) kelimesinin burada hem "boyun eğme" hem de "namazdaki secde" anlamında kullanıldığını belirtirler. Çünkü ayette göktekilerin, yerdekilerin, güneşin, ayın, yıldızların ve dağların Allah'a secde ettiğinden söz edilmekte ve hemen ardından bunlara atıfla "insanların çoğu" ifadesi yer almaktadır. Şayet secde kelimesi sadece "boyun eğme" anlamında kullanılmış olsaydı ayette anılan diğer varlıklar gibi insanların hepsi boyun eğerdi. Ancak âyette insanların bir kısmının secde ediyor olduklarından bahsedilmektedir. Demek oluyor ki bu Allah'ın hükmü ve gücü karşısında toplu bir boyun eğmekten ziyade insanların çoğunun namaz kıldıklarından ve

${ }^{66}$ Kâdı Ebû Bekr Bâkıllânî, et-Takrîb ve'l-irşâd, thk. Abdülhamit b. Ali, 2. Bs (Beyrut: Müessesetü'r-Risâle, 1998), 1/425; Râzî, el-Mahsûl, 268; Zerkeşî, el-Burhân, 2/385; İbn Müflih, Usûlül-fikh, 2/814-816.

67 Leknevî, Fevâtihu'r-rahamût, 1/165.

68 Râzî, el-Mahsûl, 274; Şehâbeddin Zencânî, Tahrîcül-usûl ale'l-furû', thk. Muhammed Edîb Salih (Beyrut: Müessesetü'r-Risâle, 1398), 313; Teftezânî, Şerhu't-Telvîh ale't-Tavdîh, 1/124.

69 Zerkeşî, el-Burhân, 2/385 vd. 
namazdaki secdelerinden söz edilmektedir. ${ }^{70}$ Bu temellendirmeye mutlak anlamda boyun eğmenin namazdaki secdeyi de kapsadığı şeklinde bir itiraz getirilebilir. Dolayısıyla "insanların çoğu" ifadesi boyun eğmenin insanlar için ihtiyari, diğer varlıklar için ise icbari olduğuna işaret etmek içindir. Ayrıca anılan ayette ‘secde etme’ fiili lafzen değilse de manen tekrar etmektedir. Yukarıda geçtiği üzere müşterek lafzın tekrar etmesi durumunda manasının değișebileceği ifade edilmektedir. ${ }^{71}$

Bu görüşte olanların delillerinden biri olan el-Ahzab suresinin 56. âyetinde geçen "salât" kelimesi de böyledir. Müşterekin umumunu savunanlara göre bu âyette "sâlat" kelimesinin anlami; Allah cihetinden rahmet, melekler açısından istiğfar ve mü'minler için dua olmak üzere üç farklı manaya gelmektedir. ${ }^{72}$ Kanaatimizce buradaki kullanımda iştirakten söz etmek pek mümkün değildir. Çünkü lafzın tekrar etmesinin yanı sıra her manasının faili de değişmektedir.

Bu bağlamda dayanak kılınan bir başka delil de “... Babalarınızın nikâhladığı kadınlarla evlenmeyin"73 âyetidir. Âyette geçen nikah kelimesinin hem evlilik akdi hem de cinsel ilişki anlamında kullanıldığı ve bunun böyle anlaşıldığı ifade edilmektedir. Buna göre âyetin getirdiği yasak babaların hem nikahladığı hem de nikahsız da olsa cinsel birliktelik yaşadığı kadınları kapsamaktadır. ${ }^{74}$ Nitekim Ebû Hanîfe ve Hanefîler başta olmak üzere müşterekin umumunu kabul etmeyenlerin görüşü de bu yöndedir. Ancak Hanefiler, âyetteki nikah kelimesinin müşterek bir lafız olduğunu kabul etmezler. Onlara göre bu lafız hakiki manada cinsel ilişki, mecazen de evlilik akdi anlamına gelmektedir. Akde nikah denmesi gerçek manası olan cinsel ilişkiye imkân tanıması ve onun sebebi olması nedeniyledir. Bu sebeple burada müşterekin değil mecazın umumundan söz edilebilir ki müşterekte umumu kabul etmeyenler bunu da caiz görmezler. Mesela Hanefîler'e göre âyetteki yasağın sebebi olarak nikahtan anlaşılan tek mana cinsel ilişkidir. Mücerret akdin de evlilik yasağının sebebi olmasını başka delillerden çıkardıklarını ifade ederler. Onlara göre bu hususun dayanağı icmadır. ${ }^{75} \mathrm{Hatta}$ Serahsî, bu âyette geçen yasağın sebebine cinsel ilişki dışında akit, helallik vb. ikinci bir mana eklemenin nassa ziyade olduğunu ifade ederek mezhebin bu konudaki tavrını açıkça ortaya koyar. ${ }^{76}$

Burada bir hususunun altını çizmek gerekir ki umûmü'l-müştereki kabul edenlere göre bu mutlak değildir. Bunun için iki şartın gerçekleşmesi gerekir. Birincisi; lafzın ifade ettiği manalardan iki veya daha fazlasını ifade etmiş olmasının mümkün/uygun olmasıdır. Bu nedenle lafzın ifade ettiği manaların birbirine zit olması durumunda

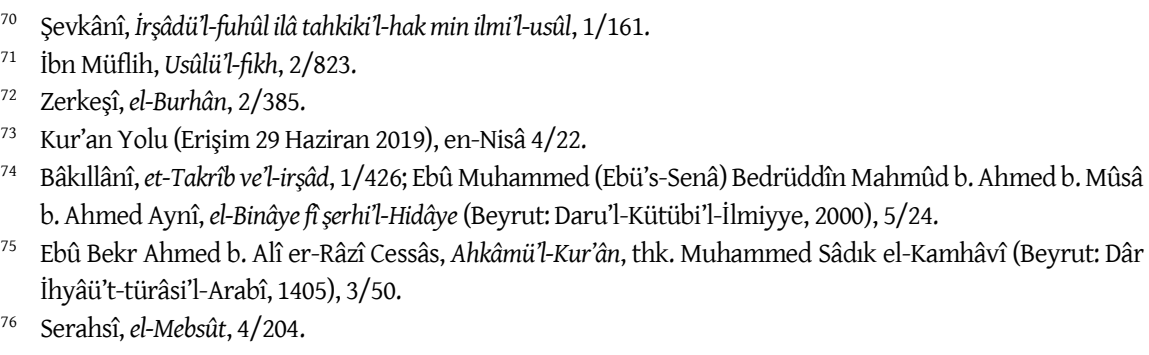

76 Serahsî, el-Mebsût, 4/204. 
umumdan söz edilemez. Mesela 'yap (إفل)' sözcügüu aynı anda emir ve tehdit anlamında kullanılamaz. Çünkü emir yapmayı, tehdit terk etmeyi gerektirir. Dikkat edilirse burada umumu engelleyen siyga veya dil değildir. Harici bir durum olan iki zıttın aynı anda meydana gelmesinin imkansızlı̆ı dır. ${ }^{77}$ İkinci şart, bu manalardan herhangi birinin kastedildiğine dair bir karine/delil bulunmamasıdır. Bu durumda konuşanın muradının hasıl olması bakımından ihtiyatlı olan müșterekin tüm manalarına hamledilmesidir. Çünkü hiçbir manasına hamledilmezse lafız ihmal edilmiş olur. Manalarından birine hamledilecek olursa sebep (muraccih) olmadan tercih söz konusu olur. İsnevînin İmam Şâfiî̀ye nispet ettiği bu açılkamalara naslardan bazı örnekler verdiği görülmektedir. ${ }^{78}$

Bu örneklerden biri, mükâtebe ${ }^{79}$ âyetindeki ${ }^{80}$ hayır (خير) kelimesidir. Âyetin meali şöyledir: “...Bedelini ödeyerek hür olmak isteyen köle ve câriyelerinizin -kendilerinde hayır görürseniz- tekliflerini kabul edin." ${ }^{81}$ Buradaki hayır kelimesinin "salih amel" ve "mal/para" olmak üzere iki anlamı bulunmaktadır. Nitekim Zilzâl suresinde; "Kim zerre miktarı hayır yapmışsa onu (karş̧lı̆ııı) görür." ${ }^{2}$ âyetinde bu kelime salih amel anlamında kullanılmıştır. Aynı kelime "Birinize ölüm yaklaştığında, eğer geriye mal bırakıyorsa anasina, babasina ve akrabasina uygun bir vasiyette bulunması, sakınanlara bir borç olmak üzere yazld.." ${ }^{33}$ ve "0, mal sevgisine aşırı derecede kapılmıştır." ${ }^{84}$ âyetlerinde mal anlamına gelmektedir. Buna göre mükâtebe yapmak isteyen kölenin hem güvenilir sâlih bir kimse olması hem de para kazanan biri olması şarttır. İsnevî daha başka örnekler de vermektedir. Ancak konuyu izah etmesi açısından bu örnek yeterlidir. ${ }^{85}$

Görüldüğü üzere burada mükâtebe âyetindeki hayır kelimesinin müşterek bir lafız olduğu, hangi manada kullanıldığına dair bir karine bulunmadığı ve iki anlamına da hamletmenin imkânı/uygunluğu varsayımından hareket edilmektedir. Buna göre yukarıda ifade edilen yaklaşım doğrultusunda Şâri'nin buradaki muradını iptal etmek yerine lafzı iki manasına da hamletme yoluna gidilmiştir. Ne var ki fikıh ve usûl literatüründe konuyla ilgili bahisler incelendiğinde bunun böyle olmadığı anlaşılmaktadır. Öncelikle ayette geçen "hayır" kelimesine iki sebepten dolayı "mal/para" anlamını vermek doğru değildir. Birincisi kölenin özel mülk edinme hakkı olmadığından malı/parası olmaz. İkincisi Arapça sahiplik lâm (J) harfi ceri ile anlatılır. Buna göre

\footnotetext{
77 Bâkıllânî, et-Takrîb ve'l-irşâd, 1/424; Zerkeşî, el-Burhân, 2/384; Dirşevî, "Mezâhibü'l-Usûliyyîn fi isti 'mâli'lmüşterek fî meânîhi meân", 237.

78 Ebû Muhammed Cemâlüddîn el-İsnevî, et-Temhîd fi tahrîicil-furû “ale'l-usûl, thk. Muhammed Hasan Hayto (Beyrut: Müessesetü'r-Risâle, 5. Bask1, 2013), 146.

79 Mükâtebe, kölenin hürriyetine kavuşmak için efendisiyle para/mal karşıllğında sözleşmesi yapmasıdır. Bk. Fahrettin Atar, "Mükâtebe", Türkiye Diyanet Vakfi İslam Ansiklopedisi (istanbul: TDV Yayınları, 2006), $31 / 360$.

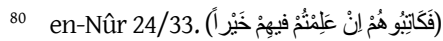

81 Kur'ân Yolu (Erişim 03 Ocak 2020), en-Nûr 24/33.

${ }_{82}$ Kur'ân Yolu (Erişim 03 Ocak 2020), ez-Zilzâl 99/7.

83 Kur'ân Yolu (Erişim 03 Ocak 2020), el-Bakara 2/180.

84 Kur'ân Yolu (Erişim 03 Ocak 2020), el-Âdiyât 100/8.

85 İsnevî, et-Temhîd, 147-148.
} 


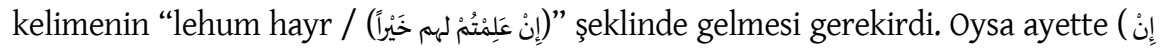

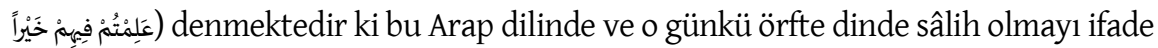
eder. Ancak ayetin hükmüne göre gayrimüslim kölelerle de mükâtebe yapılacağı sahabenin fakihleri başta olmak üzere fukahâ tarafından kabul edilen bir husustur. Buna göre ayetteki "hayır" kelimesiyle kastedilen anlamın Hz. Peygamber'in de ifade ettiği gibi "hirfet/meslek" olduğu anlaşılmaktadır. Çünkü mükâtebe akdi yapan kölenin hürriyetine kavuşması için çalışıp para kazanması gerekir. Bu da borcunu ödeme konusunda bir beceriye sahip olması anlamına gelir. ${ }^{86}$ Nitekim İbn Ömer (r.a.), Sevrî ve İmâm Mâlik'e göre bunun anlamı "kazanma gücü"dür. ${ }^{87}$

Şevkânî, müşterekin umumunu kabul edenlerin sunduğu delillerin kabul edilemeyeceğini belirtmektedir. ${ }^{88}$ Ebü'l-Hüseyn el-Basrî (öl. 436/1044), Cüveynî (öl. 478/1085), Gazzâli (öl. 505/1111), Râzî (öl. 606/1210) ve bazı Hanbeliler umumü'l-müşterekin konuşan açısından imkân dairesinde olduğu fakat bunun dilde caiz olmadığı görüşündedirler. Yani sözün sahibi müşterek lafzın tüm manalarını kastedebilir. Ancak dilde bir lafzın aynı anda birden çok farklı manayı ifade etmesi ve bu şekilde kullanılması için vazedilmiş olması düşünülemez. ${ }^{89}$

\subsection{Müşterekin Bazı Durumlarda Umumunu Caiz Görenler}

Müşterekin umumunu kabul etmeyenlerin bir kısmı, bazı durumlarda bunun caiz olduğu yaklaşımına sahiptir. Bu kapsamda nefiy başta olmak üzere tesniye ve çoğul ifadelerde müşterekin tüm manalarını aynı anda ifade edebileceği kabul edilmektedir.

\subsubsection{Nefiyde Müşterekin Umumu}

Usul alimlerinden bir kısmının yaklaşımı, umumü'l-müşterekin sadece nefiyde caiz olduğu şeklindedir. Hanefiler'den Merginânînin (öl. 593/1197) ${ }^{90}$ ve İbnü'l-Hümâm'nn (öl. 861/1457) ${ }^{91}$ benimsediği bu görüş, "olumsuzluk/nefiy umûm ifade eder" prensibine dayanır. Çünkü iştirak ile umum arasındaki ilişki 'umum-husus min vech' kabilindendir. ${ }^{92}$ Buna göre olumsuzluk cümlesinden olan nefiy ispatın aksine birden çok olabilir. Örneğin Arapçada "mevlâ" kelimesinin azat edilen köle ve kölesini azat eden efendi olmak üzere iki anlamı vardır. Buna göre hem azatlı kölesi hem de kendisini azat eden efendisi olan bir kimse, "mevlâlarıyla konuşmayacağına" dair yemin etse bunlardan herhangi birisiyle konuşursa yemini bozulmuş olur. Buna karşllık "malımın üçte biri

86 Cessâs, Ahkâmü'l-Kur'ân, 5/180-181.

87 Ebû Hafs İbn Âdil, el-Lubâbfíulûmi'l-Kitâb, thk. Adil Ahmed Abdülmevcut - Ali Muhammed Muavviz (Beyrut: Dâru'l-Kütübi'l-ilmiyye, 1998), 14/373.

88 Şevkânî, İş̧âdül-fuhûl ilâ tahkiki'l-hak min ilmil'-usûl, 1/61.

89 Basri, el-Mu'temed, 1/301; İbn Müflih, Usûlü'l-fikh, 2/81-817; Şevkânî, Irşâadül-fuhûl ilâ tahkiki'l-hakmin ilmi'lusûl, $1 / 61$.

90 Burhaneddîn Mergînânî, el-Hidâye fi şerh Bidâyeti'l-mübtedî, thk. Yusuf Tallâl (Beyrut: Dâr İhyâi't-türâsi'l'Arabî, ts.), 4/532.

91 Şemsüddîn el-Halebî İbn Emîru Hâc, et-Takrîrve’t-tahbîr (Beyrut: Dâru'l-Kütübi'l-ilmiyye, 1983), 1/213-214.

92 Semerkandî, Mizânül-usûl, 1-346. 
mevlâlarımındır" şeklinde bir vasiyette bulunsa vasiyeti geçersiz olur. Çünkü ikinci örnekte ispat vardır. ${ }^{93}$

\subsection{Tesniye ve Cemide Müş̧terekin Umumu}

Nadiren de olsa fikıh usulü kitaplarında umumü'l-müssterek hakkında dördüncü bir görüşten söz edilir. Buna göre müşterek isim tekil (müfred) olursa umumu caiz değildir. Sadece tesniye veya çoğul (cem') olması durumda umum caiz olur. Söz gelimi "arsamı mevlâma vakfettim" diyen birinin azatlısı ve efendisi hayattaysa vakıf geçersiz olur. Bunun sebebi, siygadan tek bir kişiye vakfedildiği anlaşllyor olmasına rağmen bunun kim olduğuna dair bir karinenin bulunmamasıdır. Bu durumda umûmü'l-müşterek için gerekli şartlardan biri olan tüm manalarına hamletme imkanından yoksun kalınmaktadır. Buna karşılık "arsamı mevlâlarıma vakfettim” demesi halinde her ikisine de hamletme imkânı doğar. Çünkü çoğul siyganın kullanılması birden çok kişiye vakfettiğini göstermesi açısından umuma imkân tanımaktadır. Tıpkı kur' kelimesinin çoğulunda olduğu gibi şayet kelime kur'lar (أقراء) şeklinde çoğul kipinde kullanılırsa umumu caiz olur. Kelime çoğul olduğundan konuşan bununla tuhr ve hayızdan birini kastetmiş olabileceği gibi hayız ve tuhrdan oluşan bir toplamı da kastetmiş olabilir. Kastının ne olduğuna dair bir karine yoksa umumuna hükmedilebilir. Bu görüş Şafiî usulcülerden bazılarına ve Kâdı Ebû Ya'lâ'ya nispet edilmektedir. ${ }^{94}$

Anılan görüşleri ayrı ayrı ele alarak tahlil eden Râzi, bu konuda ileri sürülen delillerin yetersiz olduğuna dikkat çeker. Ayrıca müşterek lafzın tüm manalarını aynı anda ifade etmek için vaz‘ olunmadığına dikkat çekerek, ispatta olduğu gibi nefiyde de çoğul ve tesniyede de bunu ortadan kaldıran bir durumun bulunmadığını kaydeder. Dolayısıyla bu yaklaşımın iç tutarlılıkla malul olduğuna işaret ederek müşterekin tüm manalarını aynı anda ifade edebileceğini kabul etmemektedir. ${ }^{95}$

Buraya kadar sevk ettiğimiz tartışmalardan hareketle müşterek lafı ile ilgili ihtilafın arka planda daha esaslı bir sebebe dayandığını ifade etmeliyiz. Çünkü buradaki fikir ayrılığının İslam hukuk metodolojisindeki deliller hiyerarşisi ve nesih anlayışıla ilgisi bulunmaktadır. Hanefî mezhebinin konuyla ilgili tutumuna baktığımızda bu kolaylıkla gözlemlenebilmektedir. Örneğin müşterek lafız olan kur' kelimesinin manalarından birini tercih ederken, aksini bildiren habere ve nahiv kuralına itibar etmeyip hâs lafza vurgu yapmalarının sebebi, Kitabın nassına yapılan ziyadeyi nesih olarak görmelerinden kaynaklanır. Aynı şekilde nikah lafzının sadece "cinsel ilişki" anlamında kullanımını tercih etmeleri ve akit manasının ayetle değil de icma ile sabit olduğunu ifade etmeleri de böyledir. Çünkü Hanefî usülde nassa ziyade nesih olarak görüldügünden manaya delaleti katî olan lafızların anlamını daraltmak veya genişletmek için dayanak kılınan delilin de katî olması şarttır. Bu nedenle ahad haber, kıyas, dil kuralı vb. zannî bir delile dayanarak bir lafzın manasına ikinci bir mananın eklenmesini caiz görmezler. ${ }^{96}$ Karşı görüşte olanların ise bu konuda farklı

\footnotetext{
93 Basri, el-Mu’temed, 1/305; İbn Müflih, Usûlü'l-fikh, 2/818; Leknevî, Fevâtihu'r-rahamût, 1/165.

94 Basri, el-Mu'temed, 1/304; Şevkânî, İş̧âdül-fuhûl ilâ tahkiki'l-hak min ilmi'l-usûl, 1/62.

95 Râzî, el-Mahsûl, 273.

96 Serahsî, Usulü's-Serahsî, 2/34.
} 
düşünmeleri ve İmam Şâfiî başta olmak üzere sahih olduktan sonra delil olması yönüyle hadislerin âyetlerle aynı seviyede görülmesi müşterekin umumu konusundaki yaklaşımlarına zemin teşkil etmiştir. Çünkü onlara göre nassa ziyade nesih değil tahsistir. Bu nedenle ziyadenin katî delille yapılması şart değildir. ${ }^{97}$

\section{Sonuç}

Lafızlarda çok anlamlılık çeşitli sebeplere bağlı olarak hemen her dilde bir dil problemi şeklinde lafızlarda vuku bulmuş bir olgudur. Tabiatıyla Arapça dilinde yazılı birer metin olan Kitap ve sünnet lafızlarında da görülmüş ve İslam hukuk usulünün en önemli bahislerinden birini oluşturmuştur. Literatürde şümul bakımından lafızlar ve/veya manaya delaleti kapalı olan lafızlar taksiminde ele alınan müşterek, birden çok manayı aynı anda değil de birbirinin alternatifi olarak ifade etmek üzere her bir mana için ayrı ayrı vaz‘ olunan lafızdır. Buna göre iştirakten söz edebilmek için lafzın ifade ettiği manaların tümü hakiki anlam olmalıdır. Biri hakikat diğeri mecaz şeklinde birden çok anlamı olan lafizlar müşterek kapsamında değildir.

Fıkıh usulünde müşterek lafzın manasını tespit etme konusunda iki temel yaklaşım bulunmaktadır. Hanefîler'in temsil ettiği ve çoğunluğun katıldığı görüşe göre müşterek lafızlar karşısında nassı anlamak ve gereği ile amel etmek için bu kapalılık giderilinceye kadar beklemek (tevakkuf) gerekir. Ancak kapalılı̆̆ın giderilmesi için lafzın ifade ettiği manayı araştırmak şarttır. Bu araştırma İslam hukukunun genel prensipleri doğrultusunda karineler ve deliller üzerinden yürütülür. İmam Şafiî ile birlikte bir grup usulcüye göre ise mümkün olması halinde müşterekin tüm manalarına hamledilmesi esastır. Bu imkândan yoksun olunan hallerde ise lafız muhtemel manalarından birine hamledilir. Özetle ifade etmek gerekirse naslarda yer alan müşterek lafizların hangi manaya delalet ettiğinin tespiti konusunda delil/karine ve bağlam belirleyici rol oynamaktadır.

Müşterek lafız etrafında ortaya çıkan tartışmaların en kapsamlısı ve belki de en önemlisi umumü'l-müşterektir. Bu konuda temelde üç farklı yaklaşım bulunmaktadır. Hanefîler'in başını çektiği bir görüşe göre müşterek lafızla aynı anda birden çok manası kastedilmiş olamaz. Onlara göre müşterek lafız aynı anda sadece bir anlamda kullanılır. Çünkü bu lafızlar farklı manalar için ayrı ayrı konulmuştur. Tüm manalarını aynı anda ifade etmek üzere vazedilmiş değildir. İmam Şâfiî ile birlikte birkaç usulcüye göre ise bu caizdir hatta müşterek lafızlarda kural; tüm manalarını ifade etmek için kullanılmasıdır. Bir diğer yaklaşım ise müşterekin sadece nefiy, tesniye ve çoğul siygalarda umumunun caiz olduğu şeklindedir.

Müşterek lafız, dilde her ne kadar birden çok manayı ifade etmek üzere konulmuş ise de şerî naslarda müşterek lafzın tüm manalarının veya en azından iki manasının aynı anda kastedilmiş olabileceği iddiası problemli olduğu gibi naslarda da vuku

97 Bedrüddîn Zerkeşî, el-Bahru'l-muhîtfiusûli'l-fikh (Beyrut: Dâru'l-Kütüb, 1994), 5/19; Murat Şimşek, "Hanefî Fakihlerin Haber Anlayışlarının Bir Göstergesi Olarak Nass Üzerine Ziyâde Meselesi”, İslâm Hukuku Araştırmaları Dergisi, 13 (2009), 109; Muharrem Y1lmaz, "Nassa Ziyâde Problemi ve Fıkhî İhtilâflara Etkisi (Hanefî ve Şâfiî Mezhepleri Örneğinde)”, Gaziosmanpaşa Üniversitesi İlahiyat Fakültesi Dergisi 6/1 (2018), 4 vd. 
bulmuş değildir. Çünkü müşterek lafzın çok anlamlılığı sözü işiten veya okuyan muhatap açısındandır. Bir cümlede kullanıldıktan sonra sözün sahibi veya yazarı için bu özelliğini kaybeder. Bunun sebebi, müşterek lafzı kullanan kişinin onunla manalarından sadece bir tanesini kastetmiş olmasıdır. Yani sözün sahibi müşterek lafzın tüm manalarını murat ederek muhataba "dilediğini seçebilirsin" demesi mümkün değildir. O lafızla mutlaka belirli bir manayı isteyecektir. Buradan hareketle müşterek lafzın manaya delaletindeki kapalılığın sözün muhatabı kimseler için söz konusu olduğu ortaya çıkmaktadır. Bununla birlikte müşterekin umumunu savunanların gerek dayandığı deliller gerekse verdikleri örnekler iddialarını temellendirmek için yetersiz kalmaktadir.

Kanaatimizce müşterek lafzın umumu konusunda şerî naslarla beşerî kaynakları ayrı tutmak gerekir. Naslarda geçen müşterek lafızlarda umumun caiz olmadı̆̆ı şeklindeki görüşü tercihe şayan ve isabetli görmekteyiz. Zira hikmet sahibi olan Şârî Teâla'nın ve onun adına hüküm koyma yetkisine sahip Hz. Peygamber'in (s.a.v.) tek bir lafızla birden çok mana murat etmiş olmaları düşünülemez. Her şeyden önce bu; teklifin anlaşılır olması prensibine uygun düşmemektedir.

\section{Etik Beyan / Ethical Statement}

\section{Yazar / Author}

$\mathrm{Bu}$ çalışmanın hazırlanma sürecinde bilimsel ve etik ilkelere uyulduğu ve yararlanılan tüm çalışmaların kaynakçada belirtildiği beyan olunur/It is declared that scientific and ethical principles have been followed while carrying out and writing this study and that all the sources used have been properly cited. Mahmut Samar

\section{Kaynakça}

Acar, Ömer. Anlam Değişmeleri Işı̆̆ında Kur'an'da Yeni Anlam Kazanan Kelimeler. Bursa: Emin Yayınları, 2016.

Atar, Fahrettin. "Mükâtebe". Türkiye Diyanet Vakfi İslam Ansiklopedisi. 31/360-361. İstanbul: TDV Yayınları, 2006.

Aynî, Ebû Muhammed (Ebü's-Senâ) Bedrüddîn Mahmûd b. Ahmed b. Mûsâ b. Ahmed. el-Binâye fişserhi'l-Hidâye. Beyrut: Daru'l-Kütübi'l-ílmiyye, 2000.

Bâkıllânî, Kâdı Ebû Bekr. et-Takrîb ve'l-irşâd. Thk. Abdülhamit b. Ali. 2. Bs. Beyrut: Müessesetü'rRisâle, 1998.

Basri, Ebü'l-Hüseyn. el-Mu'temed fi usûlil-fikh. Thk. Halil el-Mîs. Beyrut: Dâru'l-Kütübi'l-ilmiyye, 1403.

Cessâs, Ebû Bekr Ahmed b. Alî er-Râzî. Ahkâmü'l-Kur'ân. Thk. Muhammed Sâdık el-Kamhâvî. Beyrut: Dâr İhyâü't-türâsi'l-Arabî, 1405.

Cessâs, Ebu Bekr er-Râzi. el-Füsûl fi'l-usûl. Kuveyt: Vizâretü'l-evkâfi'l-Kuveytiyye, 1994.

Dârekutnî, Ali b. Ömer. es-Sünen. Thk. Şuayb Arnâut - Abdümünim Şelebî - Abdüllatif Hirzullah - ve Ahmed İbrahim. Beyrut: Müessetü'r-Risâle, 2004.

Debûsî, Ebû Zeyd. Takvîmü'l-edille fî usûlil-fikh. Thk. Halil Muhyiddin el-Mîs. Beyrut: Dâru'l-Kütübi'l-ilmiyye, 2001. 
Dirşevî, Abdullah Muhammed Nuri. “Mezâhibü’l-Usûliyyîn fi isti 'mâli'l-müşterek fî meânîhi meân”. Journal of Faculty of Sharia 20/20 (2002). http://hdl.handle.net/10576/9399.

Ebû Zehra, Muhammed. Usulül-fikh. Kahire: Dâru'l-Fikr, 2006.

Ferhat Koca. “Müşterek”. Türkiye Diyanet Vakfi İslam Ansiklopedisi. 32/172-174. İstanbul: TDV Yayınları, 2006.

Feyyûmî, Ahmed b. Muhammed. el-Misbâhu'l-münîr fi garibiş̧-şerhil'-kebîr. Kahire: Dâru'l-Hadîs, 2003.

Gazzâlî, Ebû Hâmid. el-Müstasfâ min ilmi'l-usûl. Thk. Muhammed Süleyman el-Aşkar. Beyrut: Müessesetü'r-Risâle, 2012.

Halîl b. Ahmed, el-Ferâhîdî. Kitâbu'l-'ayn. Thk. Mehdî el-Mahzûmî - ve İbrahim es-Sâmurâî. Beyrut: Mektebetü'l-Hilâl, 1988.

Hallâf, Abdülvehhab. İlmü usûli'l-fikh. Kahire: Dâru'l-Hadîs, 2003.

İbn Âdil, Ebû Hafs. el-Lubâb fiulûmi'l-Kitâb. Thk. Adil Ahmed Abdülmevcut - Ali Muhammed Muavviz. Beyrut: Dâru'l-Kütübi'l-ilmiyye, 1998.

İbn Emîru Hâc, Şemsüddîn el-Halebî. et-Takrîr ve't-tahbîr. Beyrut: Dâru'l-Kütübi'l-ilmiyye, 1983.

İbn Hişâm, en-Nahvî. şerh Katrin-nedâ ve belli'sadâ. Thk. Muhammed Muhyiddin Abdülhamit. Kahire, 1383.

İbn Kutluboğa, Kasım. Hülâsatüll-efkâr şerhu Muhtasaril-Menâr. Thk. Hafız Senaullah ez-Zâhidî. Beyrut: Dâr İbn Hazm, 2003.

İbn Manzûr, Muhammed b. Mükerrem. Lisânu'l-'Arab. I-XV Cilt. Beyrut: Dâr Sâdır, 3. Basım, 1993. İbn Müflih, Şemseddin. Usûlül-fikh. Thk. Fahd. b. Muhammed es-Sedehân. Riyad: Mektebetü'l'Ubeykân, 1999.

İbn Rüşd, el-Hafîd. Bidâyetü'l-müctehid ve nihâyetül-muktesıd. Kahire: Dâru'l-Hadîs, 2004.

İsnevî, Cemâlüddîn. et-Temhîd fi tahrîcil-furû‘ 'ale'l-usûl. Thk. Muhammed Hasan Hayto. 5. Bs. Beyrut: Müessesetü'r-Risâle, 2013.

Kahtân, Mahbûb. “Delâletü'l-müşterek inde'l-usûliyyin”. Mecellet Külliyeti'ş-şerîa. 3 (2012), 1-24.

Karâfî, Şihabuddin. Şerhu Tenkîhi'l-füsûl. Thk. Taha Abdurrauf Sa‘d. Kahire: Şeriketü’t-tibâe elFenniyye, 1973.

Leknevî, Bahrülulûm. Fevâtihu'r-rahamût fi şerhi Müsellemi's-sübût. Thk. Abdullah Mahmud Muhammed Ömer. Beyrut: Dâru'l-Kütübi'l-ilmiyye, 2002.

Mahallî, Celâleddîn. el-Bedrü't-tâli fí halli Cem'i'l-cevâmi'. Thk. Dâğıstâni, Murtezâ. Beyrut: Müessesetü'r-Risâle, 2005.

Mâlik, Ebû Abdillah b. Enes. el-Muvatta'. Thk. Muhammed Mustafa el-Azamî. Ebû Dabî: Müesseset Zâyid b. Sultan, 2004.

Mergînânî, Burhaneddîn. el-Hidâye fi şerh Bidâyeti'-mübtedî. Thk. Yusuf Tallâl. Beyrut: Dâr İhyâi't-türâsi'l-'Arabî, ts.

Mertoğlu, M. Suat. "Vücûh ve Nezâir". Türkiye Diyanet Vakfi İslam Ansiklopedisi. 43/141-143. İstanbul: TDV Yayınları, 2013.

Mevsılî, Mahmûd b. Mevdud. el-İhtiyâr li ta'tîli'l-Muhtâr. Thk. Muhammed Adnan Derviş. Kahire: Daru'l-Halebî, 1937.

Molla Hüsrev, Mehmed Efendi. Mirkâtü'l-vusûl ilâ ma'rifetil'-usûl fí usûli'l-fikh. Thk. İlyas Kaplan. Beyrut: Dâru'l-Kütübi'l-ilmiyye, 2012.

Muhammed Edîb, Salih. Tefsîru'n-nusûs. 4. Bs. Beyrut: el-Mektebü'l-İslâmî, 1994.

Nesefî, Ebü'l-Berekat. Menârü'l-envâr; Metnü'l-Menâr fî usûli'l-fikh. Thk. Ahmed Abdullah Abdurrahman es-Sa‘dî. Kahire: Dâr Sa‘duddîn, 2010. 
Pezdevî, Fahrulislam. Kenzü'l-Vusûl ilâ ma'rifeti'l-usûl. Thk. Sâid Bekdâş. Beyrut: Dâru'l-Beşâiri'lİslâmiyye, 2014.

Râzî, Fahreddîn. el-Mahsûl. Thk. Taha Cabir Feyyaz Ulvânî. Beyrut: Müessesetü'r-Risâle, 1997.

Semerkandî, Alâeddîn. Mizânül-usûl fì netâicil'-ukûl. Thk. Muhammed Zeki Abdüler. Doha: Matâbi'u'd-Doha el-Hadîse, 1984.

Serahsî, Şemsü'l-eimme. el-Mebsût. Beyrut: Dâru'l-Ma'rife, 1993.

Serahsî, Şemsü'l-eimme es-. Usulü's-Serahsî. Beyrut: Dâru'l-Marife, ts.

Sudirman Abbas, Ahmed. "Mevkıfü'l-fukahâ fi'l-lafzi'l-müșterek ve eserehü fi'l-fikhi'l-İslâmî”. Ahkam Jurnal Hukum Islam 36/1 (Ocak 2016).

Şaban, Zekiyyuddin. İslam Hukuk ìlminin Esasları. Trc. İbrahim Kâfi Dönmez. 30. Bs. Ankara: Diyanet Vakfi Yayınları, 2018.

Şâfiî, Muhammed b. İdris. er-Risâle. Thk. Ahmed Şakir. Kahire: Mektebetü'l-Halebî, 1940.

Şâşî. Usûlü'ş-Şâşî. Beyrut: Dâru'l-Kitâbi'l-Arabî, ts.

Şefâa, Abdülhalik. “el-Müşterekü'l-lafzî ve'l-manevî ve eseruhumâ fî ğumûdi'n-nas”. Al-Qānūn 13/1 (2016), 1-25.

Şevkânî, Muhammed b. Ali. İrşâdüll-fuhûl ilâ tahkiki'l-hak min ilmi'l-usûl. Trc. Ahmed Azzo İnâye. Beyrut: Dâru'l-Kitâbi'l-Arabî, 1999.

Şimşek, Murat. "Hanefî Fakihlerin Haber Anlayışlarının Bir Göstergesi Olarak Nass Üzerine Ziyâde Meselesi”. İslâm Hukuku Araștırmaları Dergisi. 13 (2009), 103-130.

Şîrâzî, Ebu İshak. el-Luma ‘ fi usûli'l-fikh. Thk. Eymen Salih şâbân. Kahire: el-Mektebetü’t-Tevfikiyye, 2013.

Şîrâzî, Ebû İshâk. Şerhu'l-Luma fi usûli'l-fikh. Thk. Abdülmecid Türkî. Beyrut: Daru'l-Ğarbi'lİslâmî, 1998.

Teftezânî, Sa'düddîn. Şerhu't-Telvîh ale't-Tavdîh. Mısır: Mektebet Subeyh, ts.

Türkmen, Sabri. “Arapça'da Çok Anlamlılık ve Kur'an-1 Kerim”. Diyanet İlmi Dergi. Kur’ân Özel Sayı1 (2012), 533-552.

Türkmen, Sabri. “Arapçada Çokanlamlılık ve Kur’an-1 Kerim”. Diyanet İlmi Dergi XLVI/2 (2010), 79-96.

Yılmaz, Muharrem. "Nassa Ziyâde Problemi ve Fıkhî İhtilâflara Etkisi (Hanefî ve Şâfiî Mezhepleri Örneğinde)". Gaziosmanpaşa Üniversitesi İlahiyat Fakültesi Dergisi 6/1 (2018), 1-28. https://doi. org/10.18505/cuid.686572

Zencânî, Şehâbeddin. Tahrîcül-usûl ale'l-furû'. Thk. Muhammed Edîb Salih. Beyrut: Müessesetü'r-Risâle, 1398.

Zerkeşî, Bedrüddîn. el-Bahru'l-muhît fi usûli'l-fikh. Beyrut: Dâru'l-Kütüb, 1994.

Zerkeşî, Bedrüddîn. el-Burhân fí usûli'l-fikh. Amman: Dâru'l-Kütübi, 1994.

Zeylâ̂, Osman b. Ali. Tebyînül-hakâik. 2. Bs. Kahire: el-Matbaatü'l-kübrâ el-Emîriyye, 1313. 